DOI: $10.22559 /$ folklor. 846

folklor/edebiyat, cilt:25, sayı: 97, 2019/1

\title{
Edebiyat Öğretiminde Muhafazakâr Kanon ${ }^{1}$
}

\author{
Conservative Canon in Teaching Literature
}

Tuğba Çelik*

$\ddot{O} \mathbf{z}$

Edebiyatta kanon, otoritelerin belirlediği ölçülerdeki yazar ve şairlerin bir arada anılması ve onlara benzeme koşuluyla başkalarının da bu kümeye alınmasıyla oluşur. Edebiyat öğretiminde kanon, toplumun edebiyat algısının politik bir süzgeçten geçerek oluşmasına yol açar. Bu çalışmanın amacı Türkiye'de oluşturulan dil ve edebiyat dersi öğretim programlarında en sık hangi yazar ve şairlere yer verildiğini araştırmak; bu şair ve yazarlardan bir kanon oluşturulup oluşturulmadığını ortaya koymaktır. Bu çalışmada nitel araştırma yöntemlerinden doküman analizi yöntemi kullanılmıştır. Buna göre Cumhuriyet'ten sonra Türkiye'de hazırlanan toplam yedi dil ve edebiyat dersi öğretim programı incelenmiştir. 1950 öncesindeki öğretim programlarında yazar ve şair adı bulunmamaktadır. 1950 itibariyle dil ve edebiyat dersi ögretim programlarında politik ve sanatsal bakımdan yenilikten değil gelenekten yana olan, muhafazakâr yazar ve şairlerin daha çok anıldığı bulgulanmıştır. Çalışmanın sonunda Türkiye'deki dil ve edebiyat dersi öğretim programlarında adı en sık geçen sanatçıların sırasıyla Yahya Kemal Beyatlı (20), Mehmet Akif Ersoy (17) ve Necip Fazıl Kısakürek (16) Ahmet Hamdi Tanpınar (15), Ahmet Haşim (15), Namık Kemal (13), Yunus Emre (11) ve Peyami Safa (10) olduğu görülmüş-

* Doç.Dr., Niğde Ömer Halisdemir Üniversitesi Eğitim Fakültesi Türkçe Eğitimi Anabilim Dalı Öğretim Üyesi. tcelik77@gmail.com 
tür. Anılan yazar ve şairler sanatsal ya da politik duruş bakımından muhafazakâr bir çizgidedirler ya da Cumhuriyet öncesi dönemine ait sanatçılardır.

Anahtar sözcükler: kanon, muhafazakârlık, muhafazakâr kanon, dil ve edebiyat öğretimi, öğretim programı

\begin{abstract}
In literature, canon is formed by mentioning authors and poets who meet the criteria specified by authorities together and including others in this group on condition that they resemble authors and poets in question. Canon in literature teaching paves the way for society's perception of literature to be developed through a political sieve. This study aims to investigate which authors and poets are mentioned most frequently in the Turkish language and literature curricula and observed whether a canon of these poets and authors has been formed. In this study, document analysis method which is one of the qualitative research methods is used. Accordingly, in total seven language and literature curricula published after the proclamation of Republic in Turkey were examined. It was found that no author and poet names were mentioned in the curricula published before 1950. It was observed that politically and artistically traditionalist and conservative authors and poets were mentioned in the language and literature curricula instead of those who were on the innovative side. It was seen at the end of the study that the most mentioned authors and poets in the language and literature curricula in Turkey are Yahya Kemal Beyatlı (20), Mehmet Akif Ersoy (17) ve Necip Fazıl Kısakürek (16) Ahmet Hamdi Tanpınar (15), Ahmet Haşim (15), Namık Kemal (13), Yunus Emre (11) and Peyami Safa (10) respectively. These authors and poets are artistically or politically conservative or from the pre-Republican era.
\end{abstract}

Keywords: canon, conservatism, conservative canon, teaching language and literature, curriculum

\title{
Giriş
}

Her ülkenin kendine özgü bir edebiyat öğretimi ortamı vardır. Buna bağlı olarak bir ülkenin yaşamı ve sanatı yeni kuşaklara nasıl aktardığ 1 da farklılık göstermektedir. Bu çalışmada Türkiye' deki edebiyat öğretimi ortamlarında bir yazar ve şair kanonunun var olup olmadığı, varsa bu kanonun ne tür nitelikler taşıdığı incelenmiştir.

\section{Amaç}

$\mathrm{Bu}$ çalışmanın temel amacı 'Türkiye'de yürütülen edebiyat öğretimi ortamlarına seçilen yazar ve şairlerin ağırlıklı olarak kimlerden oluştuğunu belirlemek’ olmuştur.

Alanyazında Türk edebiyatında "İnkılapçı Kanon" ya da "Milli Edebiyat Kanonu" adı verilen bir kanonun varlığından söz edilerek eğitim ortamlarında kimi yazar ve şairlerin dişlandığından söz edilmektedir (Belge, 2004; Parla, 2004; Çıkla, 2004; Anar, 2013; 
Baki, 2016). Bu çalışmada 1950’ten bu yana Türkiye'de hazırlanan dil ve edebiyat dersi öğretim programlarında adı geçen yazar ve şairlerin kimler olduğu araştırılarak Türkiye'deki edebiyat öğretiminde bir kanonun var olup olmadığ nitelikler taşıdığı ve zamanla nasıl gelişip dönüştügüünü ortaya koymak amaçlanmıştır.

$\mathrm{Bu}$ amaç doğrultusunda aşağıdaki araştırma sorularına yanıt aranmıştır:

1- 1950, 1957, 1976, 1992, 2005, 2015, 2017 dil ve edebiyat dersi öğretim programları toplamında adı en sık geçen yazar ve şairler kimlerdir?

2- 1950-2017 dil ve edebiyat dersi öğretim programlarında adı geçen yazar ve şairlerin sıklığına göre ‘İnkılapçı Kanon' ya da 'Milli/Ulusal Kanon'dan söz etmek olası midir?

3- 1950-2017 dil ve edebiyat dersi öğretim programlarında adı geçen yazar ve şairlerin sıklığına göre varsa dil ve edebiyat öğretimi programlarında ne tür bir kanonlaşma söz konusudur?

\section{Yöntem}

$\mathrm{Bu}$ çalışma analitik araştırma yaklaşımlarından doküman analizi yöntemi kullanılarak gerçekleştirilmiştir. Doküman analizi, yapılacak olan araştırmayla ilgili kayıt ve belgeleri toplamaya ve bir dizgeye göre incelemeye dayalı bir yöntemdir (Çepni, 2007: 33). Alanyazın taramasından elde edilen veriler 1şığında 1950 'den bu yana yürürlüğe girmiş olan toplam yedi dil ve edebiyat dersi öğretim programında adı geçen yazar ve şairler bir tabloya aktarılmış; yazar ve şair adlarının hangi öğretim programında ve hangi sıklıkta geçtiği yine tabloda belirtilmiştir. Böylelikle Türkiye'de uygulanan edebiyat öğretimi geleneğinde bir kanonun varlığı söz konusuysa bu kanonun nasıl nitelikler taşıdığ1 ortaya konulmuştur.

\subsection{Veri toplama}

Bu çalışmanın verilerini, 1950’den sonra Maarif Vekâleti ve Millî Eğitim Bakanlığ1 Talim ve Terbiye Kurulu Başkanlığı tarafından basılıp yayımlanmış dil ve edebiyat dersi öğretim programlarında yer alan yazar ve şairlerin adları oluşturmaktadır. Yazar ve şair adları yıllara ve sıklığa göre ayrıştırılıp düzenlenmiştir. Elde edilen veriler, çalışmanın Ek bölümünde yer alan Tablo 3'e aktarılmıştır. Tablo 3 'teki verilerin öğretim programlarının yıllarına göre ayrıştırılmasının nedeni, yıllara göre yazar ve şairlerin seçiminde bir değişiklik olup olmadığını görebilmektir. Yazar ve şair adlarının sıklığına bakılmasının nedeni ise sıklık oranının yüksekliğinin, kanonlaşmayı işaret etmesidir. İlgili alanyazın başlığı altında belirtildiği gibi kanonlaşma süreci, bazı yazar ve şairlerin adlarının diğerlerine göre daha sık anılmasıyla gerçekleşmektedir.

\subsection{Sinırlık ve varsayımlar}

Bu çalışmada 1950, 1957, 1976, 1992, 2005, 2015 ve 2017 olmak üzere toplam yedi 
dil ve edebiyat dersi öğretim programındaki yazar ve şairlerin kimler olduğu ve adlarının geçme sıklıkları belirlenmiştir (MEB, 1950; MEB, 1957; MEB, 1976; MEB, 1992; MEB, 2005; MEB, 2015; MEB, 2017). 1924, 1927, 1928, 1929 ve 1934 y1lı öğretim programlarına bu çalışmada yer verilmemesinin nedeni, bu tarihlerde yürürlüğe giren ögrretim programlarında herhangi bir yazar ve şair adına rastlanmamasıdır.

Bu çalışmada dil ve edebiyat öğretim programlarında adı 10 ve daha çok kez geçen yazar ve şairlerin bir kanon oluşturduğu varsayılmıştır. Dil ve edebiyat dersi öğretim programlarında 192'si Türk edebiyatından; Türkiye dışındaki Türk edebiyatlarındakiler dahil 55'i Dünya edebiyatından olmak üzere toplam 247 yazar ve şair adının geçtiği belirlenmiştir. Toplam yedi öğretim programında bu kadar çeşitli yazar ve şairin adı anıldığına göre kanımızca yazar ve şairlerin adlarının $10 \mathrm{kez}$ yinelenmesi bir kanonlaşma belirtisi sayılmalıdır. Daha az adı geçen yazar ve şairlerin ise öğretim programlarına zaman zaman alındıkları ve bu durumun süreğenlik göstermediği kabul edilmiş, bu yazar ve şairler olası bir kanonun üyesi olarak işaretlenmemişlerdir.

\section{3. İlgili alanyazın}

Bu başlık kapsamında, araştırmanın derinleştirilmesi ve verilerin çözümlenmesine yardımcı olacak kavramların aydınlatılması amacıyla; kanon, dünyadaki dil ve edebiyat öğretimi ortamlarındaki kanonlaşmalar, Türkiye'deki kanon tartışmaları, Yeni Türk Edebiyatı araştırmalarında kanonlaşma üzerine bazı alanyazın bilgileri alt başlıklar altında aktarılmaktadır.

\subsection{Kanon}

Kanon, Sami dilindeki "kamış" ya da "değnek” anlamına gelen bir sözcükten doğar. Yunan tarihinde kanon, insanların bir kültürel tükeniş çağında yaşadıklarına ve tek seçeneğin geçmişin başyapıtlarını kopya etmek olduğuna inandıkları bir dönemde özel bir ağırlık kazanır. Helenistik çağda kanon sözcüğü “en iyisi”, "bir üslubun en mükemmel temsilcisi” anlamına evrilmiştir. Belirli görüşteki kişiler (dinsel, felsefi, yazınsal vs.) kendi görüşlerine uygun yapıtları kanonlaştırır ve hep bu kanonun çevresinde düşünüp yorum yaparlar. Bir metin, kanona girmişse, o metinle ilgili incelemeler, araştırmalar gündeme gelir, ondan sık sık alıntılar yapılır ve böylelikle o metnin güncelliği korunur. Kanona giremeyen metinlerin ise kendi mücadelelerini vermeleri gerekir; aksi durumda kaybolma olasılıkları yüksektir. Öte yandan yaşarken kanona girememiş bir sanatçı, öldükten sonra başka görüşler taş1yan kişilerin oluşturduğu bir kanona girebilir (Jusdanis, 1998, s. 83-107). Harold Bloom (2014, s. 25-35) Dante'den Balzac'a, Borges'den Beckett'e geniş bir Batı edebiyatı kanonu tasarlamış ve bu kanonun tam ortasına Shakespeare'i koyarak onun halâ karşılaşılabilecek en özgün yazar olduğunu öne sürmüştür.

Read Herbert (1986), sanatçıların politik baskı altında kalmasının doğru olmadığını, sanatçının özgün yapıtlar vermesinin önkoşulunun özgürlük olduğunu belirtir. Politik 
niyetlerle varlık kazanan edebiyattaki kanonlaşmalar, sanatçıların da tepkilerine yol açmıştır. Örneğin kanona tepkisini kurmaca biçiminde göstermiş olan Fransız yazar Louis Ferdinand Celine, kitabının bir bölümünde şöyle söyler:

...şu koca dünyada en çok ne para eder Profesör Y Beyefendi? İstisnasız herkesin hoşuna gider? Hadi bilin bakalım bu nedir? SSCB'den Columbus, Ohiohio'ya, Kanada'nın Vancouver'ından Fas'in Fes'ine, Trabzon'dan Mexico City'ye herkesin hoşuna giden şey nedir?... Söyleyeyim 'Cila' Profesör Y, 'Cila'! 'Cila' her yerde gider, demir perdede de gider, tül perdede de gider!... Rejim falan dinlemez (Profesör Y ile Konuşmalar, 2013, s.20).

Yazar bu sözleriyle, sanatsal bakımdan özgün olmayanların adlarının sık sık basında yer almasıyla şöhrete kavuşmalarını eleştirir. Kanonda yer alan yazar ve şair metinlerinin sık sık yorumlanması ve böylelikle kutsallaştırılmaları, alanyazında da tartışmalara yol açmıştır. Türkiye'de öğrencilere öncelikli olarak hangi edebiyat metinlerinin okutulması gerektiği sorusu, kanon tartışmalarını beraberinde getirmiştir. Bundan önce dünyada uygulanan dil ve edebiyat öğretimi programlarındaki yazar ve şair seçimlerine göz atmak gerekmektedir.

\subsection{Dünyadaki edebiyat öğretimi ortamlarında kanonlaşma örnekleri}

Fransa, ortaöğretimde edebiyat dersi öğretim programlarında Antik Yunan döneminin ve Aydınlanma sonrasındaki metinlerine yer açar (Fransa Ulusal Eğitim Bakanlığı, 2018). İngiltere ise kendi aydınlanma döneminin şair ve oyun yazarı Shakespeare'i vurgular. Edebiyat dersi öğretim programında Shakespeare dışındaki İngiliz sanatçılarının adına yer verilmez. Öte yandan 18. yüzyıl sonrası İngiliz edebiyatı lise öğrencilerine öğretilirken önceki yüzyılların edebiyatı, öğretim programında yer almaz (İngiltere Hükümeti, 2018).

Rusya, Çarlık rejimini eleştiren Çehov, Turgenyev, Dostoyevski gibi halkçı ve Batı'nın aydınlanma değerlerini benimsemiş yazar ve şairleri edebiyat öğretimi ortamlarına alır (Troubina \& Chertov, 2012, s. 87-89). Çok farklı milletlerden oluştuğu için Amerika'da edebiyat öğretimi ortak bir kanondan yürütülemez; ancak Shakespeare yine de İngiliz dilinin ülkede yoğun biçimde kullanılması nedeniyle Amerikan edebiyat öğretiminde ön plandadır (Guiney, 2012, s.125-130). Amerikan üniversitelerindeki edebiyat öğretiminde de İngiliz dili ve edebiyatı ağırlıktadır. Amerika ve Kanada'da uygulanan AP dil ve edebiyat dersi öğretim programının temel amacı 'öğrencileri okumaya ve yazmaya karşı yüreklendirmek; düş güçlerini ve enerjilerini kullanarak yazınsal metinleri eleştirel bir gözle tartışmalarını sağlamaktır (Grenblatt, 2007). Bu programda metin, yazar ve şairden daha önemlidir; bu nedenle yazar ve şair adları öğretim programında geçmez.

Çin'de edebiyat öğretiminin içeriği 7. ve 10. yüzyıllar arasında yazılan şiirlerle başlar; tarihselliği ve geleneği koruyacak biçimde ilerler (Chen \& Oin, 2012, s. 47-55). Çin'in Avrupa ülkelerine göre geçmiş odaklı ve yerel kaldığı anlaşılabilmektedir. Michael Samuel (1994, s.105-106), Yeni Güney Afrika'nın edebiyat öğretimine içerik hazır- 
lama güçlüklerinden söz ettiği bir çalışmasında, Yeni Güney Afrika'daki halkın Avrupa ülkelerindekine benzer bir okuma alışkanlığının olmamasını gerekçe göstererek Avrupa tarzında bir edebiyat öğretimi içeriğinin öğrencileri sıktığından yakınır.

Avrupa ülkelerindeki edebiyat öğretimi ortamlarında modern dönem seçilir; çünkü Ortaçağ Avrupa'ya ağır bedeller ödetmiştir ve Aydınlanma öncesi dönem geride bırakılmıştır Umberto Eco (2012, s. 14) Ortaçağ kitabında 1033'teki kıtlık nedeniyle insanlık erdemlerinin nasıl yok olduğunu aktarırken Avrupa'nın Ortaçağ'a bir daha niçin dönmek istemediği açıkça ortaya koyar. Özgürlük savaşları, sınıfsal eşitlenme, bilimsel gelişmeler, Rönesans ve Reform hareketleri zaten Avrupa'nın yepyeni ve artık geri dönülemez bir medeniyete geçiş yapmasını sağlamıştır. İşte bu deneyimler Avrupa ülkelerinin pek çoğunda verilen edebiyat eğitiminin modern edebiyat metinleri odağında yapılmasını gerektirir.

Bazı ülkelerin edebiyat öğretimi politikaları, tarihte yaşamış ulusal sanatçıları, onların yapıtlarını ve öğretilerini yeni kuşaklara tanıtmaya odaklanır. Bazı ülkeler ise yerel kültürü evrensel kültürle harmanlama çabasındadır; bu doğrultuda dünya edebiyatı metinlerine sıkça yer vermektedir. Yerel olmak ya da dünyayla kucaklaşmak, o ülke için politik bir seçimdir. Emmanuel Fraisse (2012, s. 37-43) Çin, Amerika, Rusya, Senegal, Fransa, Danimarka, Haiti ve Quebec'in uzlaştırılabileceği bir edebiyat öğretimi sürecinin sonuçlarını kestirmeye çalışarak şu soruyu sorar: Evrensel bir edebiyat öğretimini sağlamak olası mıdır? Yani her ulusun üzerinde uzlaşabileceği bir evrensel yazar ve şair kanonu yaratılabilir mi? Jale Parla (2004, s. 53) da benzer soruları sorar ve şimdiye kadar dünya kanonlarını oluştururken kullanılan ve Hümanizm'den doğan evrensellik ölçütünün yeterli olup olmadığının tartışmaya açılması gerektiğini öne sürer.

Edebiyat öğretiminde evrensellikten söz edebilmek için dünya edebiyatı metinlerinden de evrensel değerleri destekleyen sanatçıların yapıtlarının dil ve edebiyat dersi öğretim programlarına alınması beklenir. Küreselleşen dünyada farklı kültürlerin edebiyatları çocuklara okutulursa, çocuklar ilginç kültürlerle tanışır, farklı kültürlerdeki insanlarla etkileşim kurmayı öğrenirler. Irkçılığın, sömürgeciliğin önüne geçilir, ortak insanlık kültürü vurgulanır, erdemler öğretilir (Tompkins, 2018, s. 362). Antal Szerb (2008, s.11), Dünya Yazın Tarihi adlı kitabında dünya edebiyatını sınırlamanın aslında o kadar da zor olmadığını, gerçek dünya edebiyatının, iyi seçilmiş bir özel kitaplığa sığabileceğini söyler.

Evrensel edebiyat öğretimi için 18. yüzyıl sonrası yazar ve şairler bir uzlaşı başlangıcı olabilir. Pek çok modern ülkenin edebiyat1, 18. yüzyıl Fransız toplumunun ve edebiyatının geçirdiği evrimden etkilenmiş ve yön değiştirmiş̧ir (Menant, 2002, s. 360). Türk edebiyatının da içinde olduğu ve bu yüzyılda değişen edebiyat çemberine İngiliz, Rus, İtalyan, Alman, Amerikan edebiyatları gibi çok sayıda ulus edebiyatı girmiştir. Dolayısıyla pek çok ülkenin 18. yüzyıl sonras1 edebiyat yapıtları, özgürlük, eşitlik, insan hakları gibi bugünkü vazgeçilmez evrensel ilkeleri kapsamında gelişmiştir. Bundan önceki edebiyat yapıtlarının evrensel konulara değinmesi bir bakıma rastlantıya dayanır. Bir başka açıdan da 18. yüzyıl öncesindeki dünyanın monarşik, otokratik vs. yapısı nede- 
niyle bu dönemde yazılmış metinlerde toplumsal cinsiyet, rrkçılık, sınıf ayrımı gibi bugüne göre sorunlu durumları içerme olasılığı söz konudur. David Damroch (2009, s. 55), Dünya edebiyatını okumanın, edebiyat ve kültürel ufkumuzu kendi kültür sınırlarımızın çok ötesinde genişletme olanağ ortamlarını yalnızca ulusal edebiyat yapıtları olarak değil dünya ölçeğinde değerli olan yapıtlar odağında da kurgulamak gerekmektedir.

\subsection{Türk edebiyatında inkılapçı ve milli/ulusal/milliyetçi kanon tartışmaları}

Türk edebiyatında II. Abdülhamid döneminden bu yana milli/ulusal/milliyetçi bir kanonlaşma olduğunu savlayan Murat Belge'ye göre (2004, s. 57-58), İttihat ve Terakki Partisi üyelerinin desteklediği ve Genç Kalemler dergisi çevresinde toplanan Ali Canip Yöntem, Ziya Gökalp ve Ömer Seyfettin bu 'milliyetçi kanon'un ilk üyeleridir. Cumhuriyet'ten sonra Namık Kemal, Abdülhak Hamid Tarhan, Recaizade Mahmut Ekrem, Tevfik Fikret, Mehmet Rauf, Mehmet Akif Ersoy, Behçet Kemal Çağlar, Yakup Kadri Karaosmanoğlu, Falih Rıfkı Atay, Ruşen Eşref Ünaydın, Halide Edip Adıvar, siyasal iktidarla uzlaştığı ya da öldükten sonra uzlaştırıldığı için kanona eklenenlerdendir. Nazım Hikmet ise bu kanonun dışına konulan, hatta 'baş belası' olarak görülen bir şair olarak hapse atılmıştır. 1950'lerden sonra Eğitim Bakanlığı eliyle 'kanon'a daha doğrudan müdahale edilebildiğini söyleyen Belge (2004, s. 59), bu dönemden sonra tek parti tipolojisine uymayan 'daha geleneksel sağcı kadrolar'ın devlet kurumlarına yerleştiği düşüncesini öne sürer ve 1960'lardan sonra çeşitlenen dünya görüşleriyle Türkiye'deki bu tekil kanonun da çeşitlendiğini, her çevrenin kendi kanonunu yarattığını ekler.

'İnkılapçı Kanon' adıyla yola çıkan Selçuk Çıkla (2004) Cumhuriyet'in kurulmasından sonra Türk edebiyatında bir inkılap kanonu oluştuğunu savlar. Türkiye'deki edebiyat ortamının kanonlaşması sırasında politik nedenlerin ön planda çıktığını vurgulayarak iktidara karşı çıkan Şinasi, Namık Kemal, Ziya Paşa, Tevfik Fikret, Halit Ziya, Mehmet Rauf, Mehmet Akif, Necip Fazıl, Nazım Hikmet gibi sanatçıların devlet tarafından türlü biçimlerde cezalandırıldıkları ve dönemin kanonundan uzaklaştırıldıklarını; buna karşın halkın kanonunda bu sanatçıların kendilerine yer edindiklerini dile getirir. Çıkla (2004, s. 59) Türkiye'de 'Ülkücü/Milliyetçi/Turanc1, Marksist, İslamcı, Kemalist' adlarıyla andığ1 toplulukların her birinin kendine ait birer edebiyat kanonunun olduğunu söyler. Bu topluluklar, kendilerine ait edebiyat kanonuna uyan yapıtlara ağırlık vermekte, onları okumakta, onların okunması için çaba harcamakta, yayınevleri de kendi kanonlarına uyan bu yapıtları sık sık yayımlamaktadır. Ona göre Mehmet Emin Yurdakul, Ziya Gökalp, Ömer Seyfettin, Ali Canip Yöntem, Ahmet Hikmet Müftüoğlu ve Aka Gündüz, Milli edebiyat kanonunun merkezini oluşturmaktadır. Çıkla (2004, s. 59) 'İnkılap Kanonu'nu ise şu isimlerle açıklar: Ahmet Kutsi Tecer, Yakup Kadri Karaosmanoğlu, Behçet Kemal Çağlar, Reşat Nuri Güntekin, Halit Fahri Ozansoy.

Türkiye'de bir 'Ulusal Kanon'un varlığını öne süren Elif Baki (2016, s.16)'ye göre 'Milli eğitim ideolojisi'nin oluşum ve gelişimi, Cumhuriyet'in kültür siyasetleriyle doğ- 
rudan ilişkilidir ve yeni bir toplum yaratmak amacıyla 'Dil İnkılabı, toplanan Dil Kurultayları, bununla bağlantılı olarak Türk Tarih Kongrelerinin vb. girişimlerle bir üst kimlik yaratma çabası'nın sonucunda lise edebiyat kitaplarında bir kanonlaşmaya yol açılmıştır. Ona göre Batı uygarlığına ayak uydurmak üzere yola çıkan Türkiye Cumhuriyeti, sözü edilen "milli" kanonlaşmayla elde edilecek bir 'milli kimlik'le aynı zamanda Osmanlı kültürünü tümüyle ortadan kaldırmayı amaçlamaktadır. Bu doğrultuda milli kimliği kurmak üzere edebiyat kitaplarına Ergenekon Destanı ya da Orhun Yazıtları gibi metinler geniş yer bulacaktır. Baki (2016, s. 173-174), 'gerekli hisleri-kahramanlık, vatan sevgisi, devlete bağlılık vs.- zaten uyandırdığı için edebi açıdan da yeterli' görülerek ders kitaplarına alınan 'Ulusal Kanon'un temel yazar ve şairlerini şöyle sıralar: Mehmet Akif Ersoy, Yakup Kadri, Halide Edip, Yahya Kemal, Ziya Gökalp, Refik Halit, Falih Rıfkı, Reşat Nuri, Mehmet Emin Yurdakul, Sait Faik, Faruk Nafiz, Necip Fazıl, Orhan Veli ve Ahmet Hamid Tanpınar. Ona göre 1950’lerin Demokrat Parti döneminde, 1960 ve 1970'li yıllarda Türkiye'de değiş̧ik ideolojik görüşteki iktidarlar gelip geçse de edebiyat ortamlarındaki bu kanon yapısı bozulmamıştır.

Turgay Anar (2013, s. 58-65) İnkılapçı/Milliyetçi kanonun varlığını doğrular ancak bu kanona karşı çıkar. O, geçmişe bağlı bir kanonun kurulmasını tercih eder. Bir edebiyat kanonunun oluşmasının gerekliğini 'geçmişinde zengin bir edebî birikim bulunan milletlerin geçmişini unutmak istememesi'ne bağlar. Dil devrimine karşı olduğunu belirten araştırmacı, 'travmatik' bulduğu 1928'deki harf devriminin Türkiye'deki insanların geçmişte yazılmış metinleri anlamasının olanaksızlaştırıldığını, sözü edilen metinlerle kurulması gereken bağın zedelendiğini öne sürmektedir. Ona göre geçmişteki metinlerle koparılan bağın bedeli, lise öğrencilerine eski metinleri okutamamakla ödenmektedir.

Hasan Öztürk (2014, s. 53) Cumhuriyet döneminden bu yana Türk edebiyatının öğretilme biçiminde bir kanonlaşmanın varlığından söz eder. 'Milliyetçilik' ve 'Çağdaşlık' kavramı odağında oluşturulduğunu düşündüğü bu kanonun, ulusal ve çağdaş olmaması nedeniyle Osmanlı dönemini reddettiği, onun yerine Orta Asya kaynaklı Türkçe metinlere yöneldiğini öne sürer. 1940'l1 yıllarda Batı klasiklerinin çevrilmesini, 1970'lerde 1000 Temel Eser'in oluşmasını da kanonlaşma olarak görür ve 2000'lerden itibaren sonra MEB'in hazırladığ 100 Temel Eser'i de bu sürece katar. Cumhuriyet ile birlikte hazırlanan her dil ve edebiyat dersi öğretim programında öğrencilere edebiyat sanatını tanıtmanın ve sevdirmenin amaçlandığını; ancak politik nedenlerle kanonik biçimde hazırlanan edebiyat programları ve ders kitapları nedeniyle bu amacın bir türlü gerçekleşmediğini söyleyen Öztürk (2014, s. 62-63), bu durumun sorumlularını tanımlamaya çalışırken kitabı nesneleştiren 'piyasa'nın, yüzdelik başarı oranının yücelten 'ÖSYM'nin, edebiyat ortamını belirleyici kanonik güçler olarak gösterir. Öztürk $(2014$, s. 61) de İnkılapçı Kanon'un Necip Fazıl Kısakürek, Nazım Hikmet, Mehmet Akif, Kemal Tahir gibi yazarları dışlandığını dile getirir. Öztürk aynı zamanda (2014 s. 60) Yahya Kemal'in 'Bir devrin edebiyatını o devrin iktidar muhitinde bulunanlar vücuda getirirler' sözünden yola çıkarak İnkılapçı Kanon'un yalnızca lise edebiyat kitaplarında sınırlı olmadığını pek çok sanatçının iktidar yanlısı kanonu desteklediğini öne sürer. 
Namık Kemal'le başlayan, dilde Türkçeleşme çabasının Türk edebiyatına iyi gelmediğini ancak artık geri dönüşün olmadığını söyleyen Orhan Koçak (2004, s. 85) şair ve yazarların dilsel bakımdan yalınlaşmaya çalışırken 'dilsiz' kaldığını öne sürmüş; Türk edebiyatında dil engelinden dolayı bir geleneğin kalmadığını bu nedenle bir kanondan söz etmenin olanaksız olduğunu düşünür. Orhan Tekelioğlu (2003, s. 66- 67) da Türk edebiyatında Ulusal Kanon'un varlığından söz ettiği çalışmasında, bu kanonun 1928'de Dil Devrimi ile gerçekleştiğini ileri sürer. Ona göre bu devrimle dile 'müdahale' edilmiş ve Ulusal Kanon’un genişletilmesi sağlanmış, Dil Devrimi le 'sayıları çok az olan okuryazarı bir anda cahil' bırakılmıştır. Ona göre yeni kuşaklar 1928'den önce yayımlanan metinlere erişimde ve bu metinleri anlamada büyük sorunlarla karşılaşmaktadır (Tekelioğlu, 2003, s. 75-76).

Hilmi Tezgör (2013, s. 51), Osmanlı'dan sonra bir üst kimliğin gerekli olduğunu ve bu nedenle dilde Türkçeleşmeyi anlamlı bulduğunu belirtir. Ona göre 1920'lerde Cumhuriyet'in kuruluş hikayesini anlatan edebiyat metinlerine gerek duyulmuş ve bu nedenle Behçet Kemal Çağlar, Reşat Nuri Güntekin, Halide Edip Adıvar gibi edebiyatçılar Cumhuriyet'in değerlerine uygun metinler yazmışlardır. Edebiyat öğretiminde 'Türk Milli Edebiyat Kanonu'ndan ya da 'Ulusal Kanon'dan söz edildiğini ve bu kanonun yerini koruduğunu dile getiren Tezgör, bunun dişında başka kanonların var olup olmadığına bakılmadığını dile getirir. Türkçe ders kitaplarına daha çok Milli Edebiyat şairlerinin metinlerinin alındığını vurgulayan Tezgör (2013, s. 52-53), bu şiirlere örnek olarak en çok Yahya Kemal'in Mohaç Türküsü ve Akıncı şiirlerinin gösterilebileceğini, Behçet Kemal Çağlar'ın şiirlerinin de ulusal kanona rahatlıkla alınabildiğini belirtir. Nazım Hikmet' in Kuvayı Milliye'si ile Ceyhun Atuf Kansu'nun Sakarya Meydan Savaşı şiirlerinin ise politik nedenlerle Türkçe ve edebiyat ders kitaplarında kabul görmediğini ekleyerek (Tezgör, 2016, s. 172), politik duruşları nedeniyle İkinci Yeni şairlerinin ve toplumcu şairlerin Türkçe ders kitaplarında hiç eşzamanlı olarak bulunamadığı aktarmıştır. Dahası, 1999'dan başlayan ve 2004'te içeriği güncellenen Türkçe ders kitaplarında Türk şiir tarihinde yer edinmemiş şairlerle karşılaşılmaya başlandığına da dikkat çekmiştir. Tekelioğlu (2003), Belge (2004), Çıkla (2004), Anar (2013), Öztürk (2014) ve Baki 'den (2016) farklı düşünen Tezgör (2013, s. 175), 1929-1945 yılları arasında basılan Türkçe ve edebiyat ders kitaplarında Türk şiirindeki biçim ve içerik değişimlerinin gerçekçi bir yaklaşımla ve iyi seçilmiş örneklerle yansıtıldığını, 1945 'ten sonra ise bu özelliğini giderek yitirdiğini öne sürmüştür. 1945 'ten sonra Türkçe ve edebiyat ders kitaplarında yalnızca Cumhuriyet' in ilk dönemlerinin şairlerine ve 'Milli edebiyat' şairlerinin şiirlerine yer verildiğini dile getirmiştir. Araştırmacı, ortaokul ders kitaplarına en çok alınan şairleri ise şöyle sıralamıştır: Tevfik Fikret, Yahya Kemal, Hececiler, Kemalettin Kamu, Ömer Bedrettin Uşaklı, Enis Behiç Koryürek ve Cahit Sıtkı Tarancı. Öte taraftan Yedi Meşaleciler (Ziya Osman Saba dışında), Toplumcu Gerçekçiler, İkinci Yeni, Özdemir Asaf ya da Can Yücel Türkçe ders kitaplarına hiç girmemiştir (Tezgör, 2013, s. 179).

Türk edebiyatında ve onun öğretiminde bir kanon varsa alanyazında bu kanonun 'Çağdaşlık' ve 'Milliyetçilik' kavramı odağında düşünülebilecek biçimde 'İnkılap- 
çı Kanon' ya da 'Ulusal/Milli/Milliyetçi Kanon' olarak tanımlandığı anlaşılmaktadır. Araştırmacıların genellikle olumsuz anlamlar yüklediği bu kanonik yapının daha çok Cumhuriyet'in ilk yılları ve tek parti dönemi siyasal iktidarlarına gönderimde bulunduğu görülmektedir. Cumhuriyet'le birlikte oluştuğu hatta İttihat Terakki'ye dek uzandığı ileri sürülen; Avrupa kültürünü benimseyen ve milliyetçi yazar ve şairlerden oluştuğu düşünülen; İnkılapçı ya da Ulusal Kanon olarak adlandırılan bu yapının 1950'lerden sonra dönüşüm geçirip geçirmediği ortaya konulmamıştır.

Beşir Göğüş (1978, s. 92), edebiyat öğretimi ortamlarında kullanılacak metinlerin niteliklerini şöyle sıralar: Neşeli insanları içermeli, ülke sevgisi ve devrimleri desteklemeli, siyasi parti desteklememeli, tarafsız olmalı, aklını zalimliğe kullananların öykülerini anlatmamalı. Bu ölçütler araştırmacının, iyimserlikten ve yeniliklerden yana olunan bir edebiyat öğretiminden yana olunduğunu göstermektedir.

Bu çalışmanın sonunda Türkiye'deki edebiyat öğretimi programlarında 1950'lerden sonra “Muhafazakâr Kanon' olarak adlandırılabilecek bir kanonun var olduğu bulgulanmıştır. Öte yandan dil ve edebiyat dersi öğretim programları kapsamında İnkılapçı ya da Milliyetçi/Milli/Ulusal Kanon olarak adlandırılabilecek bir kanonik yapı somut olarak görülememiş̧ir. Bu kanona ait yazar ve şair adları bulunsa da bunlar en sık geçenler değildir.

Muhafazakârlık kavramının ve boyutlarının açıklanmasının ardından, Tablo 3'teki verilerin ışığında oluşan bulguların yorumlanmasıyla bu çalışmada, Türk edebiyatının öğretilme geleneğindeki ‘Muhafazakâr Kanon’ betimlenmiştir. Muhafazakâr Kanon'dan önce muhafazakârlık kavramına ve Türkiye'deki geçmişine, Yeni Türk Edebiyatı araştırmalarındaki muhafazakâr kanonu betimlemek gerekmektedir.

\subsection{Muhafazakârlık}

Doğu Ergil'e göre (1986, s. 269), muhafazakârlığın bir düşünme biçimine dönüşmesi, üç önemli tarihsel olaya tepki sürecidir. İlki Fransız Devrimi'dir; yerleşik düzen alt üst olmuştur. İkincisi Sanayi Devrimidir; toplumun üretim-tüketim, emek-teknoloji gibi alışkanlıkları dönüştürmüştür. Üçüncüsü ise Aydınlanma Hareketi'dir; gelenek yerine akıl geçer ve insanın rehberi akıl olur (rasyonalizm).

1789 Fransız Devrimi'nden önceki monarşik döneme, aydınlanmacı düşünürler 'ancient regime (Fr.) ${ }^{22}$ adını vermektedirler (Caiani, 2017, s. 438). Aydınlanmacı düşünürler (Rousseau, Comte, Montesqieu vd.) Fransız Devrimi öncesindeki tüm monarşik düzen değerlerine (sınıf ayrımı, kilise baskısı vs.) karşı çıkarlar; ekonomik ve toplumsal açıdan özgürlük, eşitlik ve akılc1lıktan yana dururlar. Muhafazakârlık (Fr. conservatisme; Eng. conservatism), Fransız Devrimi'nden sonra doğan 'aydınlanmacı akıl'a karşı ortaya çıkan bir düşünce akımıdır. (Güngörmez, 2004, s. 12-13).

Edmund Burke, Reflection on the Revolution in France (Tr. Fransız Devrimi Üzerine Düşünceler) kitabıyla muhafazakârlığın kurucusu olarak tarihe geçmiştir (Özüpek, 2013, s. 67). Burke'ün muhafazakârlı̆̆ı, Aydınlanma filozoflarının akılcı düşünceleri üzerinde 
yükselen devrimci gelenekten kopuşa karşı İngiliz Devrimi'ndeki 'evrimci toplumsal dönüşüm'ün savunusudur (Duman, 2004, s. 36).

Burke'e göre reform da devrim de 'öngörülemeyen sonuçlar' doğurması nedeniyle güven vermez (Özüpek, 2013, s. 69). Muhafazakârlığın çarpıcı tanımlarından biri de zaten şudur:

O zaman muhafazakâr olmak, aşina olunanı bilinmeyene, denenmişi denenmemişe, gerçeği gizeme, fiili olanı olası olana, sınırlıyı sınırlanmamışa, yakını uzağa, kafiyi çok bol olana, elverişliyi mükemmele ve şu anki gülüşü hayali neşeye tercih etmektir (Oakeshott, 2004, s.56).

Muhafazakârlıkta değişim kavramını 'yeniye karşı yine' biçiminde tanımlayan Halis Çetin (2004, s.100) açısından modern ahlak, insanı köksüz bir ağaç gibi gelişmeye/ilerlemeye 'mahkûm etmiş' hatta insanı Tanrı, evren, doğa, toplum ve öteki ile savaşa sürüklemiştir. Yüksel Taşkın (2013, s.187) muhafazakârların 'değişim sürecinde denetimi yitirmek istemeyen' kişilerden oluştuğunu söyler. Tanıl Bora ve Burak Onaran (2013: 234) muhafazakârlığın bir ideoloji olmadığını bir karşı ideoloji olduğunu söylerler. Muhafazakârlık, günlük yaşamla sınırlı, siyasetten ayrı bir kavram değildir. Muhafazakârlık; siyasal, kültürel, sanatsal, gündelik yaşam vs. bağlamında geleneğe bağl1, her şeyi akılla açıklanması ilkesine karşı temkinli bir duruştur. Bir kişinin, siyasal partinin vs. ne kadar, hangi bakımlardan muhafazakâr olacağının sınırı ise belirsizdir. Sanatsal açıdan mı, kültürel, siyasal açıdan mı muhafazakâr bir tavır sergilendiği, genel bir muhafazakârlığın mı söz konusu olduğu her zaman tartışmaya açıktır. Muhafazakârlık da artık liberalizm, sosyalizm gibi çeşitli türlere, yaklaşımlara vs. ayrılmış görülmektedir. Yine de tüm muhafazakârlık yaklaşımlarının ortak yanının 'her şeyin bilimsel olarak açıklanmasına karşı durmak’ olduğu söylenebilir.

Besim Dellaloğlu (2016, s. 115), Tanpınar'1 ele aldığı kitabında muhafazakârlığın bütün ideolojiler gibi gelecek odaklı olduğunu söyler; ancak gelecekte değişimin olmasını değil bugünün ya da geçmişin yinelenmesini ister. Şerif Mardin (1992) ise ideolojinin bilimden ya da felsefeden farkının 'yanlılık' özelliği olduğunu söyler. Ona göre bir ideolojiye bağlı olan insan ya da toplum, başka bir düşünceyi ya da görüşü benimseyemez. Türkiye'de benimsenen muhafazakârlık ideolojisi edebiyat öğretiminde yenilikçi olanı görmemeyi doğurmuştur denebilir.

\subsection{Türkiye'deki muhafazakârlığın kısa tarihi}

Türkiye'deki muhafazakârlığın en az karşıtllık duyduğu şeyin teknoloji olduğu düşünülmektedir (Bora ve Onaran, 2013, s. 235). Teknolojik yeniliklerin Avrupa'dan da gelse Türkiye'de kabulünün kolay olmasının nedeni Tanzimat dönemi aydınlarının 'Batı'nın ilmini ve fennini alıp kültürünü almama' düşüncesine bağlanabilir. Ahmet Mithat Efendi'nin Felatun Bey'le Rakım Efendi, Recaizade Mahmut Ekrem'in Araba Sevdas1 gibi romanları hep Avrupa kültürünü bir tuzak gibi görmüş ve ona öykünmenin tehlikelerinden söz etmiştir. Cumhuriyet sonrası romanlarında da Doğu-Batı çatışması, Peyami 
Safa ve Ahmet Hamdi Tanpınar gibi önemli yazarlar tarafından defalarca ele alınmış bir konudur ve genellikle Doğu'dan yana tavır konulmuş ya da Doğu'dan vazgeçilmek istenmediğine ilişkin sezdirimlerde bulunulmuştur.

Avrupa kültürünü Türkiye'ye getirmenin yanlışlı̆̆ını 'Hans'ın röntgenini çekip Hasan'a teşhis koymak' ifadesiyle tanımlayan Çetin (2004, s. 87-88), muhafazakârlığın evrensel değerlerin ideolojik bir manipülasyon aracı olduğuna inandığını, tüm insanlığa özgü kabul edilen ilkelere kuşku ile baktığını, Fransız Devrimi ile ortaya çıkan özgürlük, eşitlik, kardeşlik ve insan hakları gibi olguları, hayal ürünü olarak değerlendirdiğini söyler. Fatih Duman (2004, s. 33), Türkiye'de muhafazakâr düşünceye yayın dünyasının fırsat verilmeyip örneğin Thomas Paine'in İnsan Hakları kitabının Türkçeye çevrildiğini ancak kitabın kendisine cevap olarak yazılan Edmund Burke'ün kitabının çevrilmediğini; Rousseau, Voltaire, Condorcet, Diderot vb. gibi dönemin Fransız filozoflarının Türkçeye çevrildiğini ancak yine bunların baş düşmanı Burke'ün çevrilmediğini söylemektedir. Oysa Türkiye'de muhafazakârlığın kökleri önce Yeni Osmanlılar'a sonra Jön Türklere kadar uzanmaktadır. Şerif Mardin (2015, s. 311), Jön Türkler'in Avrupalıların 'bürokratik muhafazakârlarının (Manheim, Durkheim vs.) etkisinde olduğunu söyler; Ahmet Mithat siyasal açıdan çok muhafazakâr olduğunu, yalnızca ekonomik ilerlemeye inandığını, damadı Muallim Naci'yi Tercüman'da aşk ve şarap şiirleri yazdığı için kovduğunu aktarır (Mardin, 2015, s. 61). Osmanlıcılık ve İslamcılık görüşlerini birleştirmeye çalışan Namık Kemal ve Ziya Paşa gibi aydınların kurduğu Yeni Osmanlılar Cemiyeti, II. Abdülhamid'e karşı meşrutiyeti savunmuştur; ancak ikisi de halkın seçtiği vekillerin yönettiği tam bağımsız bir millet meclisi yerine İngiliz tipi yarı monarşik bir millet meclisini önermişlerdir (Akyüz, 1995, s. 35; Mardin, 2015, s. 34; Uyanık, 2015). Hatta bu önerileri, üyesi oldukları Anayasa hazırlama komisyonu kararınca 'Kanun-1 Esasi' olarak 1876'da somutlaşmıştır. Mardin (2015, s. 309) Jön Türklerin en derin özlemlerinin "hürriyet" olmadığını, Jön Türklerin en büyük isteğinin Osmanlı İmparatorluğu'nun parçalanmasını durdurmak olduğunu söyler. Yani dönemin aydınları aslında Fransız tipi bir devrim değil muhafazakâr bir İngiliz tipi devrim istemiştir.

Türkiye'nin ancient regime'i Osmanlı Devleti'dir. Çokuluslu olduğu için burada milliyetçilik; saltanat ve hilafetle yönetim olduğu için inkılapçılık (devrimcilik) yoktur; devrim Osmanlı Devleti'nin son bulup yerine Türkiye Cumhuriyeti'nin kurulmasıdır. İnsel (2013, s. 618) Cumhuriyet'i kuran ve uzun süre yöneten kadroları muhafazakâr saymanın doğru olmayacağını söyler. Saltanatın ve ardından hilafetin kaldırılması alfabe, k1lik ve kıyafet, takvim ve benzeri konularda Avrupa ilkelerinin topluma kabul ettirilmesi, muhafazakâr bir görüşün yansıması olamayacak kadar devrimci yeniliklerdir. 1930'larda kültürel ve inanç açıdan Türkiye'de bir muhafazakârlığın olmadığına dikkat çeken Eric Jan Zürcher, Atatürk'ün halka yaptığı nutukların da o yıllarda dünyada yaygın olan diktatörlerin faşist/totaliter nutuklarını andırmadığına dikkat çekmiştir (Zürcher, 2008'den akt. Taşkın, 2013, s. 191). 1930'ların sonlarında Köy Enstitüleri kurulmuş ve halk önemli bir çağdaşlaşma sürecine girmiştir. Bütün bu devrimci dönüşümlerin hızı 1940'lardan itibaren azalmaya başlamıştır. Halkevleri, DTCF Folklor Kürsüsü ve 
Köy Enstitüleri, 1946 sonrası çok partili hayata geçiş sürecinde yaşanan kutuplaşmalar arasında ulusal değerlere önem vermeyen bir kuşak yetiştirmekle suçlanmışlar ve 1954 yılında Demokrat Parti hükümeti tarafından kapatılmışlardır (Öztürkmen, 2014, s. 68).

Türkiye Cumhuriyeti kurulduğunda Türkiye'deki muhafazakârlar Osmanlı'nın yeniden gelmesi için değil yeni devletin muhafazakâr olması için çabalamayı yeğlemişlerdir. Ahmet Çiğdem (2013, s.17), muhafazakârların durumu için "Geçmişi ihya etmeyi amaçlayanlar, geçmişini ihya edilmeyecek kadar geçmişte kaldığını fark ettiklerinden 'bugünü kurmayı' daha ciddi bir manada beklemişlerdir. Bu nedenle Cumhuriyet muhafazakârlığ 1 hep "ihyacı" ya da reformist bir muhafazakârlık olmuştur" der. Yani bir karşı devrimdense devrimin muhafazakâr ideolojiyle yumuşatılması sağlanmak istenmiştir. Mert (2013, s. 314-315) 1940'larda Peyami Safa, İsmail Hakk1 Baltacıŏlu, Mustafa Şekip Tunç, Hilmi Ziya Ülken gibi yazarların başını çektiği çevrenin, muhafazakâr dönüşümün öncülerinden oldukları öne sürer. 1950'lerden sonra Demokrat Parti ile 'restorasyoncu muhafazakârlık' ve 'reaksiyonerlik' öne çıkmıştır. Reaksiyoner, kendi döneminde yaşanan değişimler için mutsuz olan ve "öz yurdunda kendini sürgün hisseden"dir. Necip Fazıl Kısakürek, Osman Yüksel Serdengeçti ve Nihal Atsız, Türkiye'nin tanınmış reaksiyonerleri arasında sayılmaktadır (Taşkın, 2013, s. 200).

Kürşad Ertuğrul (2003), Türk modernleşmesinin muhafazakâr geliştiğini, modernleşmenin yalnızca Batılılaşmaya indirgendiği için bir 'öz-değerler' savunusuna dönüşerek bireyi baskı altına aldığını söyler. Şerif Mardin (2014, s. 176) ise "Türkiye 130 yıldır Batılılaşmaya çalışan bir ülke için çok yavaş" diyerek Türkiye'nin muhafazakâr bir çizgide kaldığını ima eder. Alanyazından anlaşıldığına göre Cumhuriyet’ten önce Osmanlı aydınları Avrupa'dan aldıkları görüşlerle çağdaş bir dünyanın özlemini duysalar da devrimci yerine 'reformcu' olmakla yetinmişlerdir. Mustafa Kemal Atatürk ile birlikte saltanat ve halifelik kaldırılmış, Türkiye Cumhuriyeti kurulmuş, Avrupa değerleriyle örtüşen devrimler sırasıyla gerçekleştirilmiş, laiklik kabul edilmiştir. Atatürk'ün ölümünden sonra ise muhafazakârlık hem siyasal hem edebiyat ortamlarında belirgin hale gelmiş ve Türkiye Cumhuriyeti devrimlerine yönelik eleştiriler başlamıştır.

\subsection{Yeni Türk edebiyatı araştırmalarında muhafazakâr kanon}

Bir yazarın ya da şairin muhafazakâr olduğu nereden anlaşılabilir sorusuna yanıt vermek için muhafazakâr tanımını anımsamak gerekmektedir. Yukarıda 'Muhafazakârlık' başlığı altında alanyazından elde edilen tanım ve açıklamalara göre muhafazakarlık 'yeniye karşı eskiyi savunmak, akılcılık yerine metafiziği seçmek' olarak tanımlanabilir (Oakeshott, 2004, s.56; Taşkın, 2013, s.187; Çetin, 2004, s.100). Bu tanıma göre de 'geleneksel olmayı ya da geleneksel ile uzlaşmayı seçen, yeniliğe değil eskiye bağlı olan sanatçılar' muhafazakâr sayılabilmelidir.

Türk edebiyatında geleneği yıkmak, yeniyi kurmak isteği Osmanlı Devleti'nin sonlarında başlar. Tanzimat yazarlarının pek çoğu roman, öykü, tiyatro yazarak edebiyatta yeniliği denerler. Tanzimat şairleri divan şiirini içerik bakımdan, Servet-i Fünun şairleri 
ise hem biçim hem içerik bakımından değiştirerek yenilikten yana önemli adımlar atmışlardır. Muallim Naci yenilikçi şiirden yana olmadı̆̆ i için muhafazakardır.

Kenan Akyüz (1995, s. 45-46) Ziya Paşa için şunları söyler:

Ziya Paşa'yı batılı Türk edebiyatının tam bir temsilcisi olarak kabul etmeğe imkân yoktur. Ziya Paşa'nın bütün batıcılığı, yazılarının fikir muhtevasından doğar (...) Düşünceleri ile inkılapçı olan Ziya Paşa, duyguları ile tamamıyle alışkanlıklarına bağlıdır (...) Ancak, Batı medeniyetinin kabulü bahsinde, Ziya Paşa, kapıların ardına kadar kayıtsız şartsız açılmasına değil, onun yalnız iyi yönlerinin alınmasına yani bir baraj konulmasina taraftardır.

Ziya Paşa, Şiir ve İnşa makalesinde divan şiiri ve aruz ölçüsü yerine ulusal Türk şiirini kurmak üzere hece ölçüsü ve halk şiirini savunduktan sonra Harabat'1 yazarak divan şiirine yani geleneğe döndüğünü ilan etmiştir (Akyüz, 1995, s.46). Bu nedenle Namık Kemal, Ziya Paşa'ya tepki göstererek Tahrib-i Harabat'1 yazmıştır

Nazım Hikmet 1910'lardan itibaren Türk şiirinin yönünü, dilsel ve içeriksel bakımdan yepyeni bir yola sürüklemiştir; ölçüsüz şiiri dizeyi kırarak yazmış, şiire toplumsal konuları getirmiştir (Sazyek, 1999, s.14) 1900'lerin başlarında yazmaya başlayan Mehmet Akif Ersoy ve Yahya Kemal ise biçimsel olarak eskidirler (Akyüz, 1995, s.137). Yahya Kemal, hece ölçüsü kullanımına da karşı çıkmıştır. Ona göre aruz ahenklidir, hece vezni değildir; aruz Türkçeye uygundur ve beş yüz yıllık Türk şiiri geleneğinden vazgeçmek doğru değildir (Beyatlı, 2017, s. 118). İnci Enginün, Yahya Kemal'in 'geleneğinden kopan ve sürekli arayışlarla bir asır boyu ondan uzaklaşan şiirimizi, yine geleneğe bağlayan köprüyü kurmuş' olarak tanımlamaktadır (1994, s. 55). Yine Ahmet Hamdi Tanpınar (1971, s.48'den akt. Enginün, 1994, s. 55) Yahya Kemal için 'Yahya Kemal'e klasik veya neoklasik deyişimizin sebebi Tanzimat'tan beri gelen nesillerde olduğu gibi eski şiirden ayrılma, uzaklaşma imkanlarını arayacağı yerde, onun arasından, ona yaklaşma çareleri arayarak eserini vücuda getirmesinde, hatta eski dilde yazdıklarında onu kendi bütünlüğünde yenilemesindedir” der. Böylelikle Tanpınar, Yahya Kemal Beyatlı'nın yeniliği arayan değil geleneği koruyan bir tutum içinde olduğunun altını çizmiş olur. Osmanlı döneminde II. Abdülhamit'i acımasızca eleştiren Mehmet Akif Ersoy ise Osmanlı'nın yıkılıp yerine kurulan Türkiye Cumhuriyeti'nin devrimlerini aşırı bulmuş, halifeliğin kaldırılıp laikliğin benimsenmesi üzerine 'İslam Birliği' idealine kavuşmaktan umudunu keserek Mısır'a yerleşmiştir (Akyüz, 1999, s.137; Uyanık, 2015; Timur, 2014). Bu işaretler Mehmet Akif Ersoy'un in politik bakımdan ve Yahya Kemal'in ise kültürel bakımdan muhafazakâr bir çizgide olduğunu gösterir.

I. Yeni (Garip Akımı) 1950'den önce Türk şiirinin yönünü değiştirmiş, ona yeni anlatım olanakları sunmuştur (Sazyek, 1999, s.48). II. Yeni şairleri ise Garip Akımı'na karş1 çıkarak Türk şiirini tüm şiirsel dil kullanımlara yeniden açmışlar; ancak ölçüsüz yazmayı sürdürmüşlerdir. Alışılmamış bağdaştırmalar ve dilsel sapmalar kullandıkları için de 'anlamsız' şiirler yazmakla suçlanmışlardır (Geçgel, 2011, s.173-187). Öte yandan bazı güncel Yeni Türk Edebiyatı araştırmalarında Garip şairlerine ve II. Yeni şair- 
lerine Türk şiir geleneğinin dışına çıkmaları nedeniyle sert eleştiriler yöneltilmektedir. Örnekse Ertan Örgen (2010), İkinci Yeni için şu belirlemeleri yapar:

İkinci Yeni’de dilin doğal şiir olmadığını, kelimelerin zorlandığını ve hatta bazı şiirlerin anlamını sadece şairinin bildiğini görmekteyiz. Dilin farklı bir yorumla akıldışı ve gerçeküstü konuma gelmesini istemekle anlamı da bir hayli zorlamışlar, soyut, günlük dile aykırı bir anlam düzeyi oluşturmaya çalışmışlardır (...) Anlamın rastlantısal oluşu, şairin bir şey söylememesi, kelimelerle sınırlı olarak düşünce ve duygudan hareket etmesi ebetteki yadırgatıcı aynı zamanda şiir kültürümüzün dışında kalan bir söylemdir (s. 254).

'Kelimelerin zorlanması' 'anlamın zorlanması' 'şiir kültürümüzün dışında' gibi ifadeler araştırmacının İkinci Yeni’nin şiirdeki yeni söyleyiş denemelerine olumsuz baktığını göstermektedir.

Aynı kitapta Orhan Veli ve Garip şiiri ise şöyle betimlenir:

Üstelik şiirinden, edebi üslubu, vezin ve kafiyeyi atışı, Garip’i kolay şiir mantığına götürmüş ve şiiri tanımlayacak temelleri ortadan kaldırmıştır. Bu kapıdan içeriye herkes şair diye doluşmuştur. Şiir sıradanlaşmış ve şair değer kaybetmiştir. Türk şiirinin gerçeklikle belli mesafelerle bir araya gelişi onunla hız kazanmış ve çığırından çıkmiştır (2010, s.155).

Görüldüğü gibi araştırmacı Garip şiirinin, Türk şiirinde günlük dil ve gerçeklikle iç içe yazma denemelerini yanlış bulmaktadır. Araştırmacı yine Necip Fazıl Kısakürek ve Nazım Hikmet'i karşılaştırırken Necip Fazıl Kısakürek'i Türk şiir geleneğini sürdürmek bakımından öne çıkarır:

İkisi de şiirini sosyal meselelere çevirme, şiirde müzikalite anlayışlarında beraberdirler. Ancak ayrıldıkları husus, birinin imanı kuşatan dış dünyayı, diğerinin ise iç dünyayı merkeze koymasıdır (Örgen, 2010, s. 279). (...) Necip Fazıl, döneminde ve sonradan gelenler üzerinde biraktığı etkiyle de geleneğin devamlılığı hususunda önemli bir yere sahiptir (Örgen, 2010, s. 286).

Bu belirlemeler, Nazım Hikmet'in Türk şiir geleneğini sürdürmediği ve ardından gelen şairlerin ondan etkilenmediğini düşündürür niteliktedir.

Olcay Önertoy (2001, s.106) Cumhuriyet dönemi Türk şiirini tanıttığ1 yazısında İkinci Yeni şiirini okura şöyle sunar:

Muzaffer Erdost'un adlandırdığı İkinci Yeni Hareketi, birçok yönüyle Birinci Yeni’ye karşı bir hareket özelliği taşır. Genelde, onların basitlik ve anlaşılırlık eğilimine tepkidir. İkinci Yeni’nin temel dayanakları, imge kullanmayı genişletme, özgür çağrışım, somuttan soyuta yönelme, anlamdan uzaklaşma, us dışına çıkma, kapalılık, çevreden kaçış, dilbilgisi kurallarını çiğneme ve düzgün anlatımdan kaçma olarak özetlenebilir. İkinci Yeniler bu tutumlarıyla şiiri yeniden anlaşılmaz bir duruma getirmişlerdir.

Alışılmamış bağdaştırmalar ve farklı sözdizimi kullanımları nedeniyle İkinci Yeni 
şiiri, yukarıdaki ifadelerden de anlaşıldığı gibi yine 'anlaşılmaz olmak' nitelendirilmesiyle karşı karşıya kalmıştır.

Necip Fazıl Kısakürek, metafizik içerikteki şiirleriyle ve heceyi kullanmasıyla muhafazakâr bir tutum izlediğini gösterir. Ayrıca Necip Fazıl Kısakürek Cumhuriyet devrimlerini çeşitli yazılarında, şiirlerinde, kitaplarında eleştirmiş̧ir. Örneğin Necip Fazıl Kısakürek, Son Devrin Din Mazlumları kitabının Sunuş (Takdim) bölümünde, kitabın yazılma amacını ve içeriğini şu ifadelerle belirtir:

Bu yakın tarih ve hususî plân, İttihad ve Terakki ile başlayıp Cumhuriyetle yerleştiğini gördüğümüz İslâm nefretinin zeminini çizer ve o zemin üzerinde en kuduz zalim kılıcıyla düşürülen masum başların hikâyelerini anlatır (2008, s. 1).

Bu sözler, Necip Fazıl Kısakürek'in Tanzimat'la başlayan ve Cumhuriyet'le somutlaşan laikleşmenin düşünsel olarak karşısında olduğunu yansıtır niteliktedir.

Ahmet Hamdi Tanpınar, Doğu-Batı çatışmasını konu aldığı romanlarında Batıyı tanıyan ancak Doğulu olmaktan vazgeçmek istemeyen bir duruş sergiler. Peyami Safa da Ahmet Hamdi Tanpınar gibi Türk edebiyatı tarihinde Batı'yı anlayan ancak Doğu kültürünün özelliklerinden vazgeçmek istemeyen bir yazar olarak konum alır. Bu tutumlarıyla her iki yazar da muhafazakârdır. Turan Alptekin (2015, s. 34-35), Tanpınar'ın Nazım Hikmet'in affı için imza vermesi nedeniyle dönemin muhafazakârları tarafından eleştirilip yalnız bırakıldığını aktarır. Bu duruşuyla Tanpınar'ın yeniliğe ve farklı görüşlere bağlı sanatçılara karşı dışlayıcı değil kucaklayıcı davranan bir muhafazakâr olduğu anlaşılabilmektedir.

Öykü ve romanda Orhan Kemal ve Yaşar Kemal toplumsal olayları edebiyata aktarmada ve yerel dili İstanbul Türkçesi'ne kazandırma bakımından yenilikler getirmişlerdir; bu nedenle yenilikçi yazarlardan sayılırlar. Oğuz Atay da modernist öğeleri 1970’lerde Tür romanı ve öyküsüne kazandırmasıyla dönemin eleştirmenlerini şaşkına uğratmıştır. Öte yandan Oğuz Atay dili, günümüz Türk öykü ve romancılığını hâlâ derinden etkilemektedir.

Günümüzde ve geleneksel olarak, Yeni Türk Edebiyatı araştırmacılarının muhafazakâr bir kanonu izlediği söylenebilmektedir. Bu belirleme, Türkiye'deki Yeni Türk Edebiyatı araştırmalarının önemli başvuru kaynaklarından Nihat Sami Banarlı'nın Resimli Türk Edebiyatı Tarihi II (1997), Prof. Dr. Mehmet Kaplan'ın Şiir Tahlilleri 2 (2013) ile Hikâye Tahlilleri (2010) ve Prof. Dr. İnci Enginün'ün Cumhuriyet Dönemi Türk Edebiyatı (2011) adlı kitaplarında geçen ifadelere başvurularak somutlaştırılabilir.

Nihat Sami Banarlı'nın Resimli Türk Edebiyatı Tarihi II kitabındaki bazı belirlemeler ideolojik nedenlerle bazı sanatç̧ların kanon dışına itildiğini göstermektedir. Örneğin Nazım Hikmet için şu sözleri söyler:

...şiir san'atına böyle imanlı ve disiplinli bir ruhla başlayan Nazım Hikmet yine genç yaşlarında yaptı̆̆ı bir Rusya seyahatinden sonra, memleketine her bakımdan tanınmayacak kadar değişik ve zararlı bir insan olarak döndü (...) Şiirlerindeki eski vezin 
ve şekil düzgünlüğü de yerini vezinsiz ve şekilsiz bir söyleyişe terk etmişti (Banarlı, 1997, s. 1252).

Bu sözler okuru Nazım Hikmet'in şiirine dönük olumsuz düşüncelere itecektir.

Nihat Sami Banarlı (1997) Necip Fazıl Kısakürek için ise 'Necip Fazıl da Ahmed Hamdi gibi Fransız şiiri anlayışını, fakat Türk halk şiirinin söyleyiş kıymetleriyle birleştirmek suretiyle şiirlerine daha büyük bir hayat kudreti verebilmek sırrına ulaşmış, bir cümle ile, Türk şiir lisanının söyleyiş sırlarını kavramış ve dile getirmesini bilmiş bir şairdir' (s.1255) der. Bu sözleriyle Nazım Hikmet'e yakın dönemlerde şiir yazmış olan Necip Fazıl'ı her bakımdan onayladığını vurgulamıştır. Banarlı (1997, s.1167), Yahya Kemal Beyatlı'yı da 'büyük üstat şair' olarak anar.

Banarlı, 1980'lere kadarki yazar ve şairlere yer verdiği kitabında I. Yeni’ye de (Garip) II. Yeni’ye de değinmemiş; bu şairler üzerine söz söylememiştir. Yalnızca bir kez Orhan Veli'den, o da yüzeysel bir bilgi vererek söz etmiştir. 1940'larda yazan Sabahattin Ali'den, 1950'lerden itibaren yazan Fakir Baykurt'tan, 1970'lerde yazan Oğuz Atay ve Yaşar Kemal'den, Adalet Ağaoğlu'ndan, hiç söz etmeyen Nihat Sami Banarlı, Ahmet Hamdi Tanpınar'ın, Peyami Safa'nın yapıtlarına ayrıntılıca yer vermiş ve bu yapıtları olumlar nitelikte belirlemelere yer vermiştir.

Mehmet Kaplan'ın Şiir Tahlilleri 2-Cumhuriyet Devri Türk Şiiri kitabında Nazım Hikmet soyadını değiştirdiği için sertçe eleştirilir. Ahmet Hamdi Tanpınar'ın bu haberi duyunca ne kadar üzüldüğünü, Behçet Necatigil'in Edebiyatımızda Isimler Sözlüğü’nden Nazım'ın adını çıkardığını da belirterek ona olan tepkisini 'herkesin tepkisi' imiş gibi göstermeye çabalar. Okuru ikna etmek için de şunları söyler:

Şairin içinde Türkiye’ye ve Türk milletine karşı derin bir nefret duygusunun varlığını kabul etmeden, bu son hareketlerini izah etmek mümkün değildir. Belki de o kendini bir Türk gibi hissetmiyordu (Kaplan, 2013, s. 330).

Tümüyle öznel olan bu ifadeler, bir edebiyat inceleme kapsamında kullanılmıştır.

Nazım’ın fiziksel görünüşü onun şiirini anlamak için kullanılır fakat bu ifadeler yine olumsuzluklarla doludur:

Nazım'da belki beden yapısı ve mizacıyla ilgili çok kuvvetli bir 'reaksiyon' (karşı koyma) ve 'agression' (saldırganlık) ihtiyacı vardır. Bütün şiirlerinde bunların akisleri açıkça görülür. Psikolog Henry A. Murray bu ihtiyaçları insanın karakter, şahsiyet, davranış ve hayat görüşünü tayin edici faktörler olarak izah eder. Bu duygular sosyal planda insanları ihtilalci hareketlere, kanunlara karşı koymaya sürükler (Kaplan, 2013, s. 339).

Kaplan, Nazım'ı okuyucunun karşısında utandırmak ister gibi, onun birtakım özel yaşam bilgilerini de aktarmıştır. Zaten ona olan duygularının olumsuz olduğunu gizlemez. 'Şahsına karşı beslediğim duyguları bir yana iterek diğer şairler gibi onun da eserlerini inceleyebilirdim (2013:331)' der. Bunların yanı sıra Nazım Hikmet' in onlarca şiiri dururken incelemek için 'Makinalaşmak' şiirini seçer. İncelemesinin sonlarında Nazım 
Hikmet'e yakınlık duyabilecek herhangi bir okurun kalmamasını sağlamaya çalışır gibi şu sözleri söyler:

Son zamanlarda Nazım Hikmet'i piyasaya sürenler, onu beynelmilel bir şair olarak göstermeye çalışmışlardır. Dayandıkları başlıca delil, Nazım'ın eserlerinin muhtelif dillere çevrilmiş ve hakkında övücü yazılar yazılmış olmasıdır. Yalnız bunları yapanlar umumiyetle komünistlerdir. Nazım ne hayat görüşü, ne şekil, ne de üslup bakımından dünya şiirine yeni bir şey katmış değildir. XX. Yüzyıl dünya şiirine istikamet verenler arasında, Nazım'ın belagatten ileri gitmeyen parlak ve şişkin ifadelerle dolu sığ ve fazla gürültülü şiiri büyük bir değer ifade etmez (Kaplan, 2013: 331).

Bu belirlemeler, bilimsel yolla bir şiiri çözümlemekten öte bir şairi politik nedenlerden yola çıkarak olumsuz yorumlama olarak görülebilmektedir. Bakanlar Kurulu kararıyla ölümünden 46 yıl sonra geç de olsa 2009'da Nazım Hikmet'in iade-i itibarının verilmesiyle birlikte bu gibi keskin ve kınayıcı yargılar yerine Nazım Hikmet'in Türk şiirindeki eşsiz yerini rahatça söylemek olası duruma gelmiştir.

Kaplan, Ülkü Tamer'in 'Yazın Bittiği' şiirini incelediği bölümde 'Bu nevi şiirleri tahlil ederken, adeta suçluları ihbar ve teşhir eden bir insanın durumuna düşmek endişesi taşıdığımı itiraf edeyim (...) Bir milliyetçi olarak Türkiye'yi bölmek isteyen anarşist ile komünistleri, bir insan olarak kan dökmeyi yüceltenleri tenkit hakkımdır (2013, s. 508)' diyerek eleştirmenliğini öznel ve politik görüşlerinin etkisiyle gerçekleştirdiğini ortaya koyar.

Mehmet Kaplan 'Hikâye Tahlilleri'nde Marksist görüşteki yazarları baştan silmektedir. Örneğin Yaşar Kemal'in 'Sarı Sıcak' öyküsünü incelediği yazısında 'Hikâye kahramanlarının duygu ve düşünceleri de alabildiğine basit. Hareketleri belirtmekle yetinen yazar, sebepler üzerine düşünmediği gibi, derin sayılabilecek psikolojik tahliller de yapmıyor. Şahısların duygu ve davranışları da vak'a ve dünya görüşü gibi basit ve sığ. Tek bir hikâyeye göre hüküm vermek pek doğru değilse ise de Yaşar Kemal'e usta bir hikâyeci denilemeyeceğini sanıyorum (2010: 265)' der. Araştırmac1, gerçekçi bir yazarın yalnızca olanı yansıtmaya çabaladığını bilmez gibi davranmaktadır. Kaplan, 'Uyku' öyküsünü incelediği Orhan Kemal'i beğense de politik duruşunu hatırlatarak bir kenara koyar:

Yazar, hikâyesini anlatırken objektif tasvire başvurarak kendisini gizlemeğe çalışmakla beraber, hikâyenin bütün yapısına, benimsemiş olduğu ideoloji, onun hayat ve insan görüşü, mantığı ve materyalist diyalektiği hâkimdir (2010, s. 229).

Muhafazakârlık kavramının açıklandığı bölümde söylendiği gibi muhafazakârlık akla karşı sezgiyi öne sürer. Kaplan 'On sekizinci yüzyılın sığ akılc1lığı ile on dokuzuncu yüzyılın kaba maddeciliği (2010, s. 155) ifadesiyle muhafazakâr bir edebiyat anlayış1 savunduğunu ortaya koymuş olur.

Kaplan, Ahmet Hamdi Tanpınar'ın “Adem'le Havva” öyküsünü inceler. Bu öyküde kadına soyut anlamlar yüklemesi nedeniyle Tanpınar'ı şöyle tanımlar: 
O, varlığı gerçekçilerin baktığı gibi alelade dış görünüşe göre değil, taşıdığı güzellik ve derin manaya göre tavsif ediyor (Kaplan, 2010, s. 159).

Tanpınar'1 maddeci olmaması, gerçekçi yazarlar gibi davranmaması nedeniyle yüceltir. Aynı kitapta Hüseyin Rahmi Gürpınar halkı hor gördüğü, onların batıl inançlarını ortaya dökerek onları küçük duruma düşürdügü gerekçesiyle eleştirilir. Yine politik görüşlerle belirlenen bu savlarla Hüseyin Rahmi Gürpınar'ın bir öyküsünü değerlendirilir:

Hüseyin Rahmi, hayata bakış tarzı bakımından pozitivist ve materyalisttir. Edebiyatta realizme ve natüralizme bağlıdır. $\mathrm{O}$, halk tabakalarının inançlarını ve yaşayış tarzını ilmi düşünceye aykırı bulur. Bazıları Hüseyin Rahmi’yi halkçı gösterirler. Bu bakış tarzı yanlıştır. Hüseyin Rahmi Gürpınar'a göre halk tabasına mensup insanlar, batıl inançlar içine gömülüdür. Onun eserlerinde daha sonra Ziya Gökalp'in ortaya koyduğu halk kültürüne ait müspet değerlerden hemen hemen hiçbirisi yoktur (2010, s. 35).

Bu görüşleriyle Kaplan, yine pozitivist, materyalist, akılc1, Marksist vs. yönlü düşünen tüm sanatçılara yaptığını yapar, onları muhafazakâr kanonuna almadığını ilan eder.

İnci Enginün, Cumhuriyet Dönemi Türk Edebiyatı adlı kitabında muhafazakâr bir duruş sergilediğini örneğin 'dini duyguları olmayan edebiyatı' yetersiz bulduğunu söyleyerek gösterir (2011, s.15). Bu ifadesini destekler biçimde Tanpınar ve Peyami Safa’y1 güzelliğe ve kültüre, parapsikolojiye vs. sığınarak yaşama anlam verdiklerini; ancak günümüz sanatçılarını yaşamı anlamsız buldukları ve hiçbir manevi şeye sığınmadıklarını söyleyerek eleştirir.

Beğendiği şairlerden olan ve yine muhafazakâr çizgide olduğu bilinen Yavuz Bülent Bakiler için "Yavuz Bülent Bakiler'in şiirinde hamasi bir hava görülür. Rahat söyleyişi ile sevilen şiirler yazmaktadır (Enginün, 2011, s. 111)” der. Araştırmacı bu ifadeleriyle hamasetle yazılan şiirleri beğendiğini dile getirmiş olur.

Enginün, Orhan Veli'yi şu biçimde olumsuzlar:

Orhan Veli'nin dile getirdiği boşluk ve inançsızlık, onun birçok şiirinde yer alır (...) Orhan Veli biraz daha ileri gidiyor, insanı böcekle eşit kılıyordu. Her değerden şüphelenme, onları alaya alma Orhan Veli'nin hayat görüşü olarak şiirlerine yansır (Enginün, 2011, s. 93).

Enginün'ün yazılarında; inanca yer vermemenin, maddeye değer vermenin şiiri değersizleştirdiği görüşü okura aktarılmaktadır. Oktay Rifat'ın sosyalizme yöneldiğini, Melih Cevdet Anday'ın maddeci olduğunu söyleyen araştırmacı, onlara karşı mesafeli bir ilişki içindedir (Enginün, 2011, s. 98).

Enginün'de Nazım Hikmet'e karşı siyasal nedenlerden doğan, nefrete varan bir karş1 duruşun olduğu şu sözlerinden anlaşılabilir:

Eğitimini Rusya'da yapan 'Yirmi dört saat Marks/Yirmi dört saat Lenin' ile beyni yıkanan Nazım Hikmet Ran (1902-1963), bu ideolojinin güçlü bir propagandacısıdır (Enginün, 2011, s. 61).

Asaletin kelimelerde bile düşmanı' olan şairin Türkiye'den kaçması, adını değiştir- 
mesi, bir yabancı ülkenin ve ideolojinin hizmetine girmesi yüzünden şiirlerinin yeni baskılarının yasaklanması, Nazım Hikmet' in şiir tarihimizdeki yerini bir süre adeta unutturmuştur (Enginün, 2011, s. 62-63).

Enginün (2011, s. 68) Nazım Hikmet'le genellikle karşıt olarak anılan Necip Fazıl Kısakürek için ise "Şiirlerindeki mistisizm, kapalılık, trajik söyleyiş, geleneğe bağlılık, şekil bakımdan kusursuzluk, Necip Fazıl'ın şiir tarihimizdeki yerini sağlamıştır (Enginün, 2011, s. 68)" ifadelerini kullanır.

Enginün, İkinci Yeni şairlerine sıcak bakmadığını gizlemez: İkinci Yeni şiirleri için 'günlük konuşma dilinden uzaklaşarak, anlaşılması güç bir dile dönmek, bu şiirin okunmasını da anlaşılmasını da zorlaştırmıştır (2011, s. 123)' der. Onların dilini 'karmaşık', ‘öz Türkçeden ve çeşitli yabancı dillerden alıntılarla zenginleştirilmiş' bulur ve 'çağrışım uyandırmaktan uzak kelime kadrosu kullanmak'la özdeşleştirir (Enginün, 2011, s.123). Enginün'ün Cemal Süreya'nın 'tarihe, din ve aile' gibi toplumsal kurumlara bakışının olumsuz olduğuna ilişkin yargısı (2011, s. 128) muhafazakâr okuru uyarmaya dönük bir ifade gibidir.

İnci Enginün, İkinci Yeni şairleri arasındaki tek muhafazakâr şair Sezai Karakoç’u ise över:

Dağınık imajlar ve çeşitli göndermelerle bugünü -teknik medeniyeti de içine alacak şekilde- anlatan Sezai Karakoç, hakkında yapılmış değerlendirmelerde henüz yeterince aydınlatılamamış olan şairlerdendir. Bu onun eserlerindeki derin dini bilgi ve batı edebiyatı örneklerini tanımasından kaynaklanır. Bu kaynaklara hâkim olmadan onu yorumlamak güçtür (Enginün, 2011, s. 130).

$\mathrm{Bu}$ ifadelerinden anlaşılacağı üzere Sezai Karakoç’un dışındaki diğer İkinci Yeni şairlerini anlamakta zorlandığını itiraf eden Enginün, anlamakta zorlansa da Sezai Karakoç'a yakınlık ve saygı duyduğunu sezdirir. Üstelik onu anlamamak okurun bilgi ve çağrışım dünyasının yetersizliğinden kaynaklanır. Sezai Karakoç’a karşı böylesi düşünceler taşımasının nedeni Mehmet Kaplan'dan alıntıladığı gibi Karakoç’un “milliyetçi, dindar muhafazakâr zümre’den olmasına bağlanabilir (Enginün, 2011, s. 130).

Enginün (2011, s. 131) yine Karakoç için 'Kullandığı kelimeler ve onların dayandığı güçlü İslam kaynakları Sezai Karakoç’un şiirinde gelenek ve yeninin şaşırtıcı, çekici büyüsünü kurmuş ve İkinci Yeni'nin nice şiirindeki bir gevezelik ve anlamsız kelime yığınlarına düşmekten onu korumuştur' der ve böylelikle diğer İkinci Yeni şairlerinin şiiirlerini 'gevezelik yapma'ya indirger. Dil devrimini destekleyen, bazı araştırmacıların ‘öztürkçe' diyerek dışladığı ve yadsıdığı bugünkü Türkiye Türkçesi’nin neredeyse mimarı sayılabilecek İkinci Yeni şairleri için kullanılan bu ifadeler bizce onlara yapılmış haksızlık gibi görünmektedir.

Enginün (2011, s. 297), Avrupa kültürünü eleştiren 'Doğu-Batı' karşıtlığı üzerine romanlar yazan Peyami Safa'yı da beğendiğini ifade eder. 'Yazarın materyalizmi ve onun bir uzantısı olan komünizmi reddetmesi ve güçlü kalemini bu görüşlerin savunucularına 
karşı kullanması, Peyami Safa'nın sanatının değerlendirilmesinde de taraflar oluşturmuştur. (Enginün,2011, s. 297)' der. Bu ifadelerle araştırmacı, Peyami Safa'nın politik kimliğini açık ederek onun yazarlığını da okur gözünde bir anlamda meşrulaştırır, saygınlaştırır.

Enginün (2011, s. 346), Doğu-Batı tartışmasını yürüttüğü romanlarıyla bilinen Ahmet Hamdi Tanpınar'a karşı düşündüklerini onu yüceltici ifadelerle şöyle betimler:

Onun şiirleri, roman ve hikâyeleri ile deneme ve incelemeleri, edebiyat tarihi dâhil hepsi aynı titiz, ciddi, geniş görüşlü, kültürlü sanatkârın eserleridir ve hepsine aynı bakış tarzı hâkimdir (Enginün, 2011, s. 346).

Bu ifadeler okurda Ahmet Hamdi Tanpınar'ın yazdığı hemen her şeyin değerli olduğu düşüncesini yaratır.

Enginün (2011, s. 378), 1950-1980 aras1 Türk romanına damga vuran yazarlardan olan Yaşar Kemal'e de Nazım Hikmet'e duyduğuna benzer bir tepki duyar:

Halk şairlerini ve hikâyecilerini iyi bilen yazar, yer yer kendisi de şiirli bir dil kullanır. Ancak yine de bütünüyle bu eserler fazla geveze ve roman olarak gevşek bir yapıya sahiptirler. Yazar, en meşhur eseri olan İnce Memed'in kahramanının 1925-1938 arası Toros Dağlarında dolaşan eşkıyalardan biri olduğunu eserinde açıklar. Edebiyatımızda öteden beri, fakirin koruyucusu, zorbalık karşısında dağa çıkmış yiğit eşkıya tipi mevcuttur. Yaşar Kemal gelenekte bulunan bu hazır konuyu kullanmıştır (Enginün, 2011, s. 378).

$\mathrm{Bu}$ ifadelerden araştırmacının Yaşar Kemal'in dilini 'geveze' kurgusunu 'gevşek' bulduğu başarısız bir romancı olarak gördüğü, roman konularını da halk öykülerinden aldığı için onu özgün olmamakla suçladığı anlaşılır. Oysaki Yaşar Kemal, halk motiflerini çağdaş edebiyata taşıması ve halk dilini Türkiye Türkçesine taşıması bakımından değerli ve uluslararası ün kazanmış bir Türk edebiyatı yazarıdır.

Enginün, Yaşar Kemal'i uluslararası ünü nedeniyle de eleştirir:

Yaşar Kemal'in yurt dışındaki şöhretinde iyi bir pazarlamanın etkisi olduğu gibi batılının bir sömürge gibi görmek istediği Anadolu tasvirlerinin etkisi de bulunmaktadır. Etrafında büyük bir propaganda yığını bulunan Yaşar Kemal de benzeri bazı yazarlar gibi ayrıntılı değerlendirmelerden henüz uzaktır (Enginün, 2011, s. 377).

Enginün, Oğuz Atay’la ilgili yalnızca bir paragraf yazmış ve yüzeysel belirlemeler yapmıştır (Enginün, 2011, s. 392). Çağdaş Türk edebiyatı okurunu ve yazarlarını derinden etkilemiş Oğuz Atay’ı İnci Enginün'ün görmezden gelmesi ya da yüzeysel olarak anlatması, Oğuz Atay’ın muhafazakâr bir duruşta betimlenmeyecek kadar aykırı bir yazar olmasıyla da açıklanabilir. Oğuz Atay, İnci Enginün'ün dikkatini çekmez; dolayısıyla onunla ilgilenmez. Öte yandan Enginün, Emine Işınsu için bir buçuk sayfa, Mustafa Kutlu iki buçuk sayfa yer ayırmıştır (Enginün, 2011, s. 397-399). 'Gören göze ve göstermesini, düşündürmesini bilen bir ifadeye sahip’ olduğunu düşündüğü Mustafa Kutlu’ya olan sevgi ve saygısını Enginün şu ifadelerle dile getirir: 
Mustafa Kutlu her yıl küçük bir ciltte çıkardığı kitaplarda, toplumun her kesimine bir teselli sunmaya devam etmektedir (2011, s. 413).

Gerek Emine Işınsu'nun gerekse Mustafa Kutlu'nun muhafazakâr bir bakış açısıyla yapitlar ortaya koyduğu da bilinen bir durumdur.

Nihat Sami Banarlı, Mehmet Kaplan ve İnci Enginün'ün çalışmaları incelendiğinde görülen ortak tutumun, Türk edebiyatında muhafazakâr bir çizgiyi benimsemek ve bu çizgideki sanatçıları ön plana çıkarmak olduğu anlaşılmaktadır.

\section{Bulgular}

Bu çalışmanın amacı Türkiye'de hazırlanan dil ve edebiyat dersleri öğretim programlarında geçen yazar ve şair adlarının bir kanon oluşturup oluşturmadığını belirlemek, varsa bu kanonun ne tür nitelikler taşıdığını ortaya koymaktır. 1950, 1957, 1976, 1992, 2005, 2015 ve 2017 dil ve edebiyat dersi öğretim programlarında adı geçen yazar ve şairler sıklıklarına ve yıllarına göre durumu, Ek 1'deki Tablo 3'te yer almaktadır. Bu tablodaki veriler, çalışmanın alt araştırma sorularına yanıt verecek biçimde başlıklar altında yorumlanmıştır.

4.1. 1950, 1957, 1976, 1992, 2005, 2015 ve 2017 dil ve edebiyat dersi öğretim programları toplamında adı en sık geçen yazar ve şairler kimlerdir?

1950-2017 tarihleri arasındaki dil ve edebiyat dersi öğretim programlarında adı 10 kezden çok geçen şair ve yazarlar Tablo 1'de sıralanmaktadır.

Tablo 1: 1950-2017 tarihleri arasında dil ve edebiyat dersi öğretim programlarında adı 10 kez ve daha çok geçen yazar/şairler ve sıklıkları

\begin{tabular}{|l|l|}
\hline Yazar/Şair Adı & Sıklık \\
\hline Yahya Kemal Beyatlı & 20 \\
\hline Mehmet Akif Ersoy & 17 \\
\hline Necip Fazıl Kısakürek & 16 \\
\hline $\begin{array}{l}\text { Ahmet Hamdi Tanpınar } \\
\text { Ahmet Haşim }\end{array}$ & 15 \\
\hline Namık Kemal & 14 \\
\hline Yunus Emre & 11 \\
\hline Peyami Safa & 10 \\
\hline
\end{tabular}

Ad1 10 kez ve daha çok anılan yazar ve şair sayısı 8'dir. Ahmet Hamdi Tanpınar ve Ahmet Haşim'in sıklığı birbirine denktir. 
1950-2017 tarihleri arasındaki dil ve edebiyat dersi öğretim programlarında adı 5 kez ve daha çok geçen şair ve yazarlar Tablo 2'de sıralanmaktadır:

Tablo 2: 1950-2017 tarihleri arasındaki dil ve edebiyat dersi öğretim programlarında adı 5-10 kez geçen yazar/şairler ve sıklıkları

\begin{tabular}{|l|l|}
\hline Yazar/Şair Adı & Sıklık \\
\hline $\begin{array}{l}\text { Recaizade Mahmut Ekrem } \\
\text { Ömer Seyfettin } \\
\text { Halit Ziya Uşaklıgil } \\
\text { Reşat Nuri Güntekin } \\
\text { Ahmet Muhip Dıranas }\end{array}$ & 8 \\
\hline $\begin{array}{l}\text { Mustafa Kemal Atatürk } \\
\text { Abdülhak Hamid Tarhan } \\
\text { Ziya Gökalp } \\
\text { Yakup Kadri Karaosmanoğlu }\end{array}$ & \\
\hline $\begin{array}{l}\text { Halide Edip Adıvar } \\
\text { Faruk Nafiz Çamlıbel } \\
\text { Cahit Sitkı Tarancı }\end{array}$ & 7 \\
\hline $\begin{array}{l}\text { Ahmet Mithat } \\
\text { Ziya Paşa } \\
\text { Fuat Köprülü } \\
\text { Mehmet Kaplan }\end{array}$ & 6 \\
\hline
\end{tabular}

Ad1 5-10 kez geçen yazar ve şair sayısı 16'dır. Birbirinden farklı yazar ve şairlerin ögretim programlarında geçme sıklığ $18,7,6$ ve 5 'tir.

4.2. 1950-2017 Dil ve edebiyat dersi öğretim programlarında adı geçen yazar ve şairlerin sıklığına göre ‘inkılapçı kanon' ya da 'milli/ulusal/milliyetçi kanon'dan söz etmek olası mıdır?

1950-2017 dil ve edebiyat dersi öğretim programlarında ad1 $10 \mathrm{kez}$ ve daha çok geçen yazar ve şairler arasında alanyazında sınırları belirlenmiş olan İnkılapçı Kanon ya da Milli/Ulusal Kanon yazar ve şairler yoktur. Bu kanona dahil edilecek yazar ve şairlerden olan Ömer Seyfettin (8),), Reşat Nuri Güntekin (8), Mustafa Kemal Atatürk (7), Yakup Kadri Karaosmanoğlu (7), Ziya Gökalp (7), Halide Edip Adıvar (6) Fuat Köprülü (5), Faruk Nafiz Çamlıbel (6) ancak 5-10 kez adı geçenler arasındadırlar, öğretim programlarına seçilme sıklığı bakımından ikincil durumdadırlar. 
4.3. 1950-2017 Dil ve edebiyat dersi öğretim programlarında adı geçen yazar ve şairlerin sıklığına göre varsa dil ve edebiyat öğretimi programlarında ne tür bir kanonlaşma söz konusudur?

Ek bölümünde yer yer alan Tablo 3 verilerinden yola çıkarak 1950'den bu yana hazırlanan dil ve edebiyat dersi öğretim programlarında adı en az 10 ve daha çok kez geçen sanatçıların ilk üçü sırasıyla Yahya Kemal Beyatlı (20), Mehmet Akif Ersoy (17), Necip Fazıl Kısakürek (16) olarak belirlenmiştir. Bu sanatçıların ortak yanı sanatsal bakımdan geleneği izlemeleri; akılcı ve modern bir devlet olan Türkiye Cumhuriyeti'nin devrimlerin bazılarını ya da tümünü benimsememiş olmalarıdır. Üçü de şair olan bu sanatçılar, Osmanlı döneminden kalma toplumsal kurallarına, Osmanlı dönemi şiir geleneğine bağlı kalmayı önemsemişler; yaşadıkları çağı da bu bağlamda eleştirmişlerdir (Enginün, 1994, s. 55; Uyanık, 2015; Örgen, 2010, s.286; Banarl1, 1997, s.1255; K1sakürek, 2008, s.1; Tanpınar, 1971, s. 48'den akt. Enginün, 1994, s.55). Ahmet Hamdi Tanpınar (15) ve Peyami Safa (10) da bu çizgide ilerlemişler; yapıtlarını bu duyarlıkla kaleme almışlardır. Namık Kemal (14) Yunus Emre (11) ve Ahmet Haşim (15) ise Cumhuriyet öncesi dönem sanatçılarıdır.

Edebiyat öğretiminde muhafazakâr kanon, birden bire oluşmamıştır. Bu oluşumun süreç içindeki gelişimini yine Tablo 3 verilerinden yola çıkılarak betimlemek gerekmektedir:

1950 ve 1957 öğretim programlarında Batı edebiyatına önem verilir. Homeros, Platon, Euripides, Moliere, Montaigne, Shakespeare, Dante, Tolstoy, Stendhal, Flaubert, Goethe, Balzac, Ibsen, Mark Twain, E. A. Poe ve daha pek çok sanatçı bu öğretim programlarında yer alır. Bu tutumuyla bu öğretim programlarının Avrupa edebiyatının ve kültürünün izlediği düşüncesini uyandırmaktadır.

1950 ve 1957 dil ve edebiyat dersi öğretim programı için Cumhuriyet döneminden seçilen sanatçılar, Reşat Nuri Güntekin, Yakup Kadri Karaosmanoğlu, Halide Edip Ad1var gibi Milli Edebiyat; Ziya Gökalp ve Mehmet Emin Yurdakul gibi milliyetçi; Mehmet Akif Ersoy ve Yahya Kemal gibi muhafazakâr yazar ve şairlerden oluşmaktadır. Türkiye Cumhuriyeti'nin ilk yıllarında politik bakımdan dönemi eleştiren Refik Halit Karay ve Nazım Hikmet'in adları, 1950 ve 1957 dil ve edebiyat dersi öğretim programlarında geçmemektedir. Refik Halit Karay, yalın Türkçesi ile özellikle işçi ve köylü kadın sorunlarını ilk kez dile getiren gerçekçi Türk edebiyatı yazarlarındandır (Sülükçü, 2008, s. 449). Nazım Hikmet ise Türk şiirinizin dize yapısını ve sözvarlığını değişime uğratmıştır. Bu iki yenilikçinin adı 1950'lerin öğretim programlarında görülmemektedir. Öte yandan bu iki isimden daha genç olan Orhan Veli, Oktay Rifat ve Melih Cevdet, Sait Faik, Orhan Kemal, Sabahattin Ali, Yaşar Kemal'in adı da bu programlarda yoktur (Maarif Vekaleti, 1950; Maarif Vekaleti, 1957). Oysa bu sanatçılar Türk edebiyatında yepyeni bir dili kurmuş ve Türk edebiyatının yönünü değiştirecek atılımlar yapmış şair ve yazarlardır. Türk edebiyatına dilsel ve içerik bakımından yenilik getiren toplumcu gerçekçilere ve Garip şairlerine öğretim programlarında yer açılmaması yalnızca politik olarak okunmamalı, 
edebiyatta yenilikçiliğin değil gelenekçiliğin yeğlendiğini göstermektedir.

Prof. Dr. Mehmet Kaplan (MEB, Tebliğler Dergisi, 1976) tarafindan hazırlanan fakat kısa sürede yürürlükten kaldırılan 1976 dil ve edebiyat dersi öğretim programı, aslında 1992 öğretim programının hazırlayıcısıdır. 1976 dil ve edebiyat dersi öğretim programında Avrupa edebiyatı ile araya mesafe konulmuştur:

Doğu ve Batı edebiyatlarından insan, aile, vatan sevgisi gibi duyguları telkin eden, ahlaki ve estetik değere haiz parçalar. Tagor, İkbal, Sadî, Hafız, Hayyam, Racine, Molière, Shakespeare, Goethe'den örnekler üzerinde çalışlacaktır. (T.C. MEB Tebliğler Dergisi, 1976, s. 344).

Avrupalı sanatçılara ayrılan yerin 'Batı edebiyatlarından insan, aile, vatan sevgisi gibi duyguları telkin eden, ahlaki ve estetik değere haiz parçalar' ifadesiyle daraltırlmasında, Avrupa edebiyatının Türkiye'nin geleneksel değerlerine aykırı olabilecek metinlerle dolu olduğu düşüncesi gizlidir. Herhangi bir sınırlayıcı açıklama verilmeksizin Hintli ve Arap sanatçılara yer açılması da Doğu'nun değerlerinin Türkiye için daha kabul edilebilir sayıldığının belirtisi sayılmalıdır. Muhafazakârlığın boyutu Divan ve Halk edebiyatı sanatçılarının sayılarının artırılmasından da anlaşılmaktadır: Erzurumlu Emrah, Bayburtlu Zihni, Seyrani, Fuzuli, Baki, Nef'i, Nabi, Latifi, Naili... Orhan Veli'nin adı ilk kez 1976'da hem de 3 kez görülür aslında; ancak yürürlüğe girmeyen bu öğretim programının ardından Orhan Veli'nin adı ancak 1 kez, 1992 öğretim programında görülecektir. Örneğin 2005 öğretim programında adı 9 kez geçen Necip Fazıl, yine 8 kez adı geçen Mehmet Akif Ersoy'a karşı onun adı hiç geçmez.

1992 dil ve edebiyat dersi öğretim programında Halk edebiyatı ve Divan edebiyatı, 19. ve 20. yüzyıl edebiyatı karşısında ağırlığını artırmış, ikinci derecede tanınırlığı olan sanatçılar bile öğretim programına alınmıştır: Erzurumlu İbrahim Hakkı, Niyazi-i Mısri, Âşık Ömer vs. Mevlâna, ilk kez bu öğretim programında görülmektedir. Bu durum, Osmanlı Devleti'nin kültür ve sanatına daha çok yakınlık duyulduğunu düşündürmektedir. Öte yandan 1992 programı ilk kez Sait Faik'i, Haldun Taner'i, Nurullah Ataç'1, Orhan Kemal'i, Cahit Sitkı Tarancı'yı, Yaşar Kemal'i kapsamına almıştır. Ancak yine Nazım Hikmet, Refik Halit Karay, Sabahattin Ali, II. Yeni Şairleri ve Orhan Veli dışındaki I. Yeni şairleri öğretim programında yer almamaktadır. 1970'lerin sonunda çağdaş Türk edebiyatını derinden etkileyen Oğuz Atay'a da yer açılmadığını belirtmek gerekir. 1992 öğretim programı Türkiye Cumhuriyeti dışındaki Türkçe edebiyata özellikle önem verir (Bahtiyar Vahapzade, Cengiz Aytmatov vd.). Bu dönemde Türkiye'nin SSCB'den ayrılıp sırayla bağımsızlığa kavuşan Türk devletleriyle bir bağ kurmaya çalıştığı anlaşılmaktadır. 1992 dil ve edebiyat dersi öğretim programında Stendhal, Shakespeare, Montaigne, Racine, Tolstoy, Goethe gibi çok bilinen 14 Avrupalı sanatçıya yer açılmasının, Avrupa sanatı ve kültüründen tümüyle vazgeçilmediğini düşündürmektedir.

2005 'te Nazım Hikmet ve Refik Halit Karay ve II. Yeni şairlerinin adları Türkiye'de ilk kez bir dil ve edebiyat öğretimi programına girer. Öte yandan bu öğretim programı muhafazakâr yazar ve şairlere kapılarını sonuna dek açmıştır: Arif Nihat Asya, Cahit 
Zarifoğlu, Erdem Beyazıt, Yavuz Bülent Bakiler, Mehmet Çınarlı, İlhan Geçer, Mustafa Kutlu, Semiha Ayverdi, Hacı İbrahim Efendi... En sık anılan şairler Necip Fazıl (9), Mehmet Akif Ersoy (8), Ahmet Haşim (8), Yunus Emre (7) ve Ahmet Muhip Diranas (5)'tır. Görüldüğü gibi muhafazakâr yazar/şair yoğunluğu ve sıklıkları 2005'te artış göstermiştir.

2005 dil ve edebiyat dersi öğretim programlarında Avrupa edebiyatından yazar ya da şaire yer verilmemiştir. Halk edebiyatı ve Divan edebiyatı sanatçılarının sayısında da bir azalma söz konusu değildir. 2005 öğretim programının Nazım Hikmet (2) ve Refik Halit Karay’a (1), II. Yeni şairlerinden bazılarına (Sezai Karakoç, Cemal Süreya, Edip Cansever; İlhan Berk) ilk kez yer vermesi olumlu bir gelişme olarak görülmelidir. Bunun yanı sıra Türk edebiyatının yüz akı sayılabilecek Sabahattin Ali’ye, Yaşar Kemal'e, Ülkü Tamer'e bu öğretim programında da yer açılmaması ve bu durumun 2015 ve 2017'de yinelenmesi düşündürücüdür.

2015-2017 öğretim programlarında milliyetçi ya da muhafazakâr yazarlar yerlerini korur. Bu çizginin dışında kalan tek yazar Orhan Kemal'dir. En çok adı geçen şairler Yahya Kemal Beyatlı (9), Mehmet Akif Ersoy (3) ve Necip Fazıl Kısakürek’tir (2). Muhafazakâr şair ve yazarlar kanonu arasına İsmet Özel, Mustafa Kutlu, Sedat Umran, Niyazi Y. Gençosmanoğlu eklenir. 2015-2017 dil ve edebiyat dersi öğretim programında şairler ağırlıktadır. Halk edebiyatı ve Divan edebiyatı sanatçılarının "dili anlaşılır” olanlarına ağırlık verilmesi önerilmiştir (MEB, 2015, s.18; MEB, 2017, s.17).

\section{Sonuç ve tartışma}

Dil ve edebiyat ders kitaplarının öğretim programında yer alan tüm kazanımları karşılayacak biçimde kurgulanması zorunludur; öğretim programları öğretmenlerin ve ders kitabı yazarlarının öğretim planlamalarını yönlendirmektedir (MEB, 2017, s.1316; MEB, 2015, s. 8-16). Bunun anlamı öğretim programında yer alan her tür konunun, etkinliğin, kavramın, yazar ya da şairin ders kitabında yer alması gerekmektedir. $\mathrm{Bu}$ gerekçeyle bu çalışmada, Türk edebiyatının öğretilme sürecinde bir kanonun var olup olmadığı, varsa bu kanonun ne tür özellikler gösterdiğini belirlemek üzere ders kitaplarına değil temel kaynağa yani Türkiye'de yayımlanmış/yürürlüğe girmiş dil ve edebiyat dersi öğretim programlarına başvurulmuştur.

1950’lere kadar dil ve edebiyat öğretim programlarında herhangi bir yazar ve şair adına rastlanmamıştır. Bu tutum demokratik bir duruşun belirtisidir. Cumhuriyetin ilk 27 yılında dil ve edebiyat dersi öğretim programlarında hiçbir yazar ve şaire yer verilmemiştir. $\mathrm{Bu}$ yılların öğretim programlarında yalnız amaçlar, beceriler, konular vs. bulunmaktadır. 1950'den sonra ise yazar ve şair adları verilmeye başlanmıştır. Bu adlar arasında ad1 10 kez ve daha çok geçenler Yahya Kemal Beyatlı, Mehmet Akif Ersoy, Necip Fazıl Kısakürek, Ahmet Hamdi Tanpınar, Ahmet haşim, Namık Kemal, Yunus Emre ve Peyami Safa'dir.

Alanyazında, Türk edebiyatının öğretilme sürecinde İnkılapçı ve Milliyetçi/Milli/ Ulusal Kanon olduğu üzerine tartışmalar yürütülmüştür (Belge, 2004; Çıkla, 2004; Anar, 
2013; Baki, 2016). Bu tartışmalar ders kitaplarındaki metinlerden yola çıkılarak ya da sanatçıların iktidarlarla kurdukları ilişkilere dayandırılmıştır. Baki'ye göre (2016, s. 177) ideolojik söylemle ve faydacı yaklaşımla yola çıkan Cumhuriyet'in edebiyat öğretimi programlarının, edebiyatı sevdirme ve sanattan haz alma amacından tümüyle uzaklaşılmıştır. Baki (2016), Cumhuriyet'ten itibaren başlayan Ulusal Kanon'un 1980'e kadar sürdüğünü ileri sürmektedir; ancak bu çalışmanın bulguları, 1950'den sonra İnkılapçı Kanon'a değil Muhafazakâr Kanon'a işaret etmektedir. Baki (2016), Çıkla (2004), Belge (2004), Anar (2013) gibi araştırmacıların daha çok 1950’lerden önceki döneme gönderimler yaparak Türk edebiyatında İnkılapçı ya da Milliyetçi/Millî /Ulusal bir kanonun olduğuna yönelik bulguları dikkate değer olsa da dil ve edebiyat dersi öğretim programlarının metinleri ele alındığında 1950'lerden sonra ortaya başka bir yelpaze çıkmaktadır.

İnkılap, devrim yani yenilik demektir. Cumhuriyet döneminin ilk yazar ve şairleri genellikle yenilikleri savunmuşlardır. Reşat Nuri Güntekin, Yakup Kadri Karaosmanoğlu, Faruk Nafiz Çamlıbel bu sanatçıların en başarılı olanlarındandır. Nazım Hikmet ve Refik Halit Karay gibi dönemin siyasal iklimiyle bazı açılardan örtüşmeyenler ise uzun süre ders kitaplarından saf dışı edilmişe benzemektedirler. 2005 yılına dek bu isimleri dil ve edebiyat dersi öğretim programlarında da görmek olanaksızdır.

Mardin'in (1992) ideolojilerin her zaman yanlı olduğu belirlemesine dayanarak dil ve edebiyat dersleri için seçilen yazar ve şairlerin herhangi bir ideolojik bağlamda seçilmemesini gerektirir. Muhafazakârlık ya da yenilikçi olmak gibi özellikler, sanatçılar arasında bir ayrım yapmak gerektiğini düşündürmemelidir. Bir sanatçının değeri kuşkusuz muhafazakâr olup olmamasıyla, yenilikçi olup olmamasıyla ilgili değildir. Sanatçıyı değerli kılan dilde özgünlük, içerikte benzersizliktir.

Türkiye Cumhuriyeti kurumlarının temelleri, Osmanlı Devleti'nin son dönemlerinden itibaren başlayarak özellikle Fransa olmak üzere Avrupa ülkelerinden esinlenerek oluşturulmuştur (Mardin, 2015, s. 356) Pek çok kanun, hak ve özgürlükler bu bağ ile gerçekleştirilmiştir (Mardin, 2015, s. 342). Roman, öykü, tiyatro gibi türler Avrupa edebiyatından öğrenilerek geliştirilmiştir. Bu nedenle, 1992'ye dek dil ve edebiyat dersi öğretim programlarında Avrupa edebiyatı az ya da çok sayıda yazar ve şairle dil ve edebiyat dersi öğretim programlarında yerini almıştır. Ancak 2005'ten itibaren Avrupa edebiyatı, öğretim programlarından çıkarılmıştır.

Türkiye'deki dil ve edebiyat öğretimi programları tarihinde 1950'lerden itibaren divan ve halk şiirine dönüş vardır. Yunus Emre, Fuzuli, Baki en sık geçenlerdendir. Bu sanatçıların metinlerini anlamak öğrenciler için her zaman güç olmuştur. Bundaki ısrarın nedeni öğrencilerin Türkiye Cumhuriyeti öncesiyle bağ kurmasını sağlamaya çalışmaktır. Bu uğurda 2015-2017 dil ve edebiyat dersi öğretim programlarına dek yaklaş1k 65 yıl boyunca öğrencilere divan ve halk şiiri ağırlıklı dil ve edebiyat dersi içeriği sunulmuştur. 2015-2017 dil ve edebiyat dersi öğretim programlarında bu yoğunluk önemli ölçüde azaltılmıştır; çünkü 65 yıl içinde pek çok muhafazakâr yazar/şair yetişmiş ve kabul görmüştür. Böylelikle muhafazakâr güncel yazar ve şairlerin sayısı 2015-2017 dil 
ve edebiyat dersi öğretim programlarında artırılmıştır. Yenilikçi olan ya da gelenekseli reddeden yazar ve şairlere ayrılan yer yok denecek kadar azdır.

Edebiyat öğretimi ortamlarında çeşitliliğin görülmesi gerekmektedir. Oysa Türk edebiyatındaki çok sayıdaki gelenek karşıtı/yenilikçi yazar ve şairin varlığına karşın dil ve edebiyat dersi öğretim programlarında bu adlara yer verilmediği görülmektedir. Örneğin 1976 öğretim programında, bu tarihe kadar çoktan ün kazanmıs Sabahattin Ali, Necati Cumal1, Tarık Buğra, Aziz Nesin, Attila İlhan, Fakir Baykurt, Haldun Taner, Cemal Süreya, İlhan Berk, Edip Cansever, Turgut Uyar, Ece Ayhan, Gülten Akın, Sezai Karakoç ve Behçet Necatigil gibi adlar yoktur. Hiçbir öğretim programında Melih Cevdet Anday ve Sabahattin Ali yoktur. 2005'te adı ilk kez geçen Nazım Hikmet, Türk şiirine sunduğu içerik ve biçimsel katkıları hak edecek biçimde dil ve edebiyat dersi öğretim programlarında henüz yer almamaktadır.

Muhafazakâr kanonun varlığını destekler biçimde Banarlı (1997, s. 1257), Kaplan (2013, s. 508), Enginün (2011, s. 93) gibi Türkiye'de çağdaş Türk edebiyatı üzerine çalışan pek çok araştırmacı, yenilikçi yazar ve şairlere dönük öznel, yargılayıcı ifadeler kullanmışlardır. Bu tutumun hem dil ve edebiyat öğretmenlerinin hem çağdaş edebiyat araştırmacılarının bakış açılarını daraltıış olabileceği hem ortaöğretim düzeyindeki öğrencilere dar bir edebiyat öğretimi çerçevesi sunmaya yol açmış olabileceği düşünülmelidir.

Türk edebiyatı zengin bir edebiyattır. Cumhuriyet’ten bu yana, Türkçeyi ve Türk edebiyatını nice yeniliğe ve dönüşüme uğratmış yazar ve şairler yetişmiştir. Bu gerçeğin 1şı̆̆ında şu soruları sormamız gerekir:

1- Dil ve edebiyat dersi öğretim programlarında muhafazakâr yazar ve şairleri önceleyip, yenilikçi yazar ve şairleri ikincil düzeyde bırakmak ya da onları gözden kaçırmak doğru ve yeterli bir dil ve edebiyat öğretimini sağlar mı?

2- Geleceğin yaratıcı ve nitelikli yazar ve şairlerini yetiştirmek için öğrencilere Türk edebiyatının yenilikçi ve çağdaş yazar ve şairlerini sunmak yararlı olabilir mi?

3- Kanonlar yerine politik niyetlerden uzaklaş1lmış, sanatın özgür ve özgünlügünün kabul gördüğü bir dil ve edebiyat öğretimi ortamı daha demokratik bir toplumu ve iklimi beraberinde getirebilir mi?

Yukarıdaki sorulara verilecek yanıtlar yeni araştırmalara konu olabilecek niteliktedir. Dil ve edebiyat derslerinde bir kanon izlemek yerine, kanonlardan kaçınmak gerekir. Çünkü her kanon politiktir, dolayısıyla sınırlayıcıdır. Sanatçılara politik önyargılarla yaklaşmaktan uzak durulmalıdır; çünkü sanat özgürdür ve varlığıyla zaten yararlıdır. Yapıtları ve sanatçıları değerlendirirken sanatsal ölçüler kullanılmalıdır.

Dil ve edebiyat öğretimi ortamlarında, dünyada da tanınan ve Türk edebiyatının önemli sanatçılarına gerekli değer verilmeli, öğrencilerin onları tanımaları ve okumaları sağlanmalıdır. Bunların yanı sıra dünya edebiyatına yön veren, Türk edebiyatının da içinde bulunduğu Avrupa edebiyatına kapılar yeniden açılmalıdır. Balzac, Dostoyevski, Shakespeare vs. okumamış bir öğrencinin evrensel ölçülerde bir edebiyat kültürüne yak- 
laşma olasılığı düşüktür. Hatta Uzak Doğu ve Güney Amerika gibi dünya edebiyatlarının önde gelen yazar ve şairlerine de dil ve edebiyat öğretim programlarında yer açarak öğrencilerin edebiyat sevgisini ve edebiyat kültürünü beslemek gerekmektedir.

\section{Notlar}

1-Bu çalışma, İstanbul Okan Üniversitesi'nde gerçekleştirilen Uluslararası Türkçenin Eğitimi ve Öğretimi Kurultayı'nda (UEOK 2017) sunulan 'Kültürel Model Bağlamında Türkiye’deki Edebiyat Öğretiminde Kanon' başlıklı sözlü bildiriden geliştirilerek hazırlanmıştır.

2-'Ancient regime', sosyal bilimlerde terimleşmiştir. Türkçedeki anlamı 'eski yönetim biçimi' dir. Bu terim, modern öncesi dönemdeki her türlü geleneğe, töreye, yasaya vs. işaret eder.

\section{Kaynaklar}

Akyüz, K. (1995). Modern Türk edebiyatının ana çizgileri. Ankara: İnkılap.

Alptekin, T. (2015). Tanpınar'ın ölümü. İstanbul: Yapı Kredi.

Anar, T. (2013). Türk edebiyatında edebiyat kanonu: Kanon, kanona girmek ve kanona müdahale, FSM İlmî Araştırmalar İnsan ve Toplum Bilimleri Dergisi, 1, 40-78.

Baki, E. (2016). Ulusun inşası ve resmi edebiyat kanonu (2. Baskl). İstanbul: Libra.

Banarlı, N. S. (1997). Resimli Türk edebiyatı tarihi II. İstanbul: Milli Eğitim.

Beyatl1, Y. K. (2017). Edebiyata dair. İstanbul: İstanbul Fetih Cemiyeti.

Bloom, H. (2014). Batı kanonu. (Ç. Pala Mull. Çev.) İstanbul: İthaki.

Belge, M. (2004). Türkiye'de kanon, YKY Kitaplık Dergisi, 68, 54-59.

Bora, T. Onaran, B. (2013). Nostalji ve muhafazakârlık-mazi cenneti. A. Çiğdem (Ed), Modern Türkiye'de siyasi düşünce cilt 5/muhafazakârlık (ss 234-260). İstanbul: İletişim.

Caiani, A. A. (2017). Re-inventing the ancien regime in post-napoleonic Europe. European History Quarterly, 47(3) 437-460.

Celine, L. F. (2013). Profesör Y ile konuşmalar. (A. Erkay. Çev.) İstanbul: YKY.

Chen W. Oin, L. (2012). La littérature à l'école en Chine, Revue Internationale d'Education Sevres, Dossie Ensegnement et Literature dans le Monde, 62, 47-58.

Çepni, S. (2007). Araştırma ve proje çalışmalarına giriş. Trabzon: Celepler.

Çetin, H. (2014). Muhafazakârlık: Kaosa karşı kozmos. Muhafazakâr Düşünce Dergisi, 1(1), 87-119.

Çıkla, S. (2004). Türk edebiyatında kanon ve inkılap kanonu. Muhafazakâr Düşünce Dergisi, 4 (13-14), 47-68.

Çiğdem, A. (2013). Sunuş. A. Çiğdem (Ed), Modern Türkiye'de siyasi düşünce. Cilt 5/ muhafazakârlık (ss.13-19). İstanbul: İletişim.

Damrosch, D. (2009). Dünya edebiyatı nasıl okunmalı? (D. Çetinkasap. Çev.) İstanbul Bilgi Üniversitesi. İstanbul.

Dellaloğlu, B. (2016). Modernleşmenin zihniyet dünyası: Bir Tanpınar fetişizmi. Ankara: Kadim.

Duman, F. (2004). Edmund Burke muhafazakârlık, aydınlanma ve siyaset, Muhafazakâr Düşünce Dergisi, 1(1), 31-53. 
Eco, U. (2012). Ortaçağ-barbarlar, Hristiyanlar, Müslümanlar. (L. Tonguç Basmacı. Çev.) İstanbul: Alfa Tarih.

Enginün, İ. (1994). Şiirimizin klasik şairi Yahya Kemal Beyatlı. Doğumunun yüzüncü yılında Yahya Kemal Beyatl, (ss. 51-55). Ankara: Atatürk Kültür Merkezi.

Enginün, İ. (2011). Cumhuriyet dönemi Türk edebiyatı. İstanbul: Dergâh.

Ergil, D. (1986). Milliyetçilik, muhafazakârlık, halkçılık. Ankara: S.

Ertuğrul, K. (2003). Türkiye modernleşmesinde toplumsal ve bireysel özerklik sorunu: Oğuz Atay ve Orhan Pamuk'la birlikte düşünmek. Doğu Batı Dergisi, 6 (22), 91-105.

Fraisse, E. (2012). L'enseignement de la literature: un monde a explore. Revue Internationale d'Education Sevres, Dossie Ensegnement et Literature dans le Monde, 62, 35-45.

Grenblatt, E. (2007). AP English literature and composition teacher's guide, College Board Advanced Placement Program. San Francisco. California.www.collegeboard.com.

Göğüş, B. (1978). Orta dereceli okullarımızda Türkçe ve yazın eğitimi. Ankara: Kadığlu.

Guiney, M.M. (2012). L'enseignement général de la littérature aux États-Unis existe-t-il? Revue Internationale d'Education Sevres, Dossie Ensegnement et Literature dans le Monde, 62, 121-131.

Güngörmez, B. (2004). Muhafazakâr paradigma: Dogma ve önyargı. Muhafazakâr Düşünce Dergisi, 1(1), 11-33.

Herbert, R. (1986). Sanat ve toplum. (S. Mülayyim. Çev.) Ankara: Umran.

İnsel, A. (2013). Düzen mi kalkınma mı? A. Çiğdem (Ed), Modern Türkiye'de siyasi düşünce Cilt 5/Muhafazakârlık (ss. 616-621). İstanbul: İletişim.

Jusdanis, G. (1998). Gecikmiş modernlik ve estetik kültür. (T. Birkan. Çev.) İstanbul: Metis.

Kaplan, M. (2010). Hikâye tahlilleri. İstanbul: Dergâh.

Kaplan, M. (2013). Şiir tahlilleri 2. Cumhuriyet Devri Türk Şiiri. İstanbul: Dergâh.

K1sakürek, N.F. (2008). Son devrin din mazlumları. (26. Baskı), İstanbul: Büyük Doğu.

Koçak, O. (2004). Kanon mu, siz inanıyor musunuz? YKY Kitaplık Dergisi, 68, 60-68.

Koçakoğlu, B. Öztinar, G. (2017). İnkılapçı kanonun izinde gerçek hikâyeye doğru: Dikmen Y1ld1z1 okumalar1 / In pursuit of the revolutionist canon towards the real story: Dikmen Y1ldızı readings. Selçuk Üniversitesi Edebiyat Fakültesi Dergisi, (38), 33-58.

Mardin, Ş. (1992). İdeoloji. İstanbul: İletişim.

Mardin, Ş. (2015). Türk modernleşmesi. İstanbul: İletişim.

MEB. (1950). Tebliğler Dergisi. 571, 1. Millî Eğitim Bakanlı̆̆1.

MEB. (1952). Lise müfredat programı. Ankara: Millî Eğitim Bakanlı̆̆ı.

MEB. (1957). Lise müfredat programı. Ankara: Maarif.

MEB. (1976). Tebliğler Dergisi. 1901 (39), 341-349. Millî Eğitim Bakanlı̆̆1.

MEB. ( 1992). Tebliğler Dergisi. 2370 (55), 813-839. Millî Eğitim Bakanlığı.

MEB. (2005). Türk edebiyatı dersi öğretim programı ve kılavuzu. Ankara: Millî Eğitim Bakanlığı.

MEB Talim ve Terbiye Kurulu Başkanlığı (2015). 2015 Türk dili ve edebiyatı dersi ögretim programı. Millî Eğitim Bakanlığı.

MEB Talim ve Terbiye Kurulu Başkanlığı (2017). 2017 Türk dilli ve edebiyatı dersi ögrretim programı. Millî Eğitim Bakanlığı.

Menant, S. (2002).Literature et enseignement: la reduction polymathique. Revue histoire literaire de la France.102,355-364.

Mert, N. (2013). Muhafazakârlık ve laiklik. A. Çiğdem (Ed.). Modern Türkiye'de siyasi düşünce. Cilt 5/Muhafazakârlık (ss. 314-315). İstanbul: İletişim. 
Oakeshott, M. (2004). Muhafazakâr olmak üzerine. (İ. Seyrek. Çev.) Muhafazakâr Düşünce Dergisi, 1(1), 55-78.

Önertoy, O. (2001). Cumhuriyet dönemi Türk edebiyatında şiir. Çağdaş Türk edebiyatı: Illköğretim ögretmenliği lisans tamamlama programı. Eskişehir: Anadolu Üniversitesi.

Örgen, E. (2010). Türk şiirinde gelenek. Cumhuriyet dönemi Türk şiiri. Konya: Palet

Öztürk, H. (2014). Aynadaki rüya- Sesten simgeye geçiş romanlar ve romancılar. (2. Baskı). İstanbul: Metamorfoz.

Öztürkmen, A. (2014). Türkiye'de folklor ve milliyetçilik. İstanbul: İletişim.

Özüpek, B. B. (2013). Muhafazakârlık, devrim ve Türkiye. A. Çiğdem (Ed.). Modern Türkiye'de siyasi düşünce. Cilt 5/Muhafazakârlık (66-83), İstanbul: İletişim.

Parla, J. (2004). Edebiyat kanonları. YKY Kitaplık Dergisi, 68, 51-53. ISSN: 1300-0586.

Samuel, M. (1996). Learning and teaching literature: A curriculum development perspective. Ninth Conference on South African Literature, Pedagojic of Reconstruction: teaching Literature in a 'New South Afrika' Bad Boll, Germany 14-16 October, 94-107.

Sazyek, H. (1999). Cumhuriyet dönemi Türk şiirinde Garip hareketi. Ankara: İş Bankası.

Sülükçü, Y. (2008). Refik Halit Karay'ın öykülerinde kadın. Y. Kocadoru ve G. Çakır Damaoğlu (Ed.) Bir bilim kategorisi olarak 'Kadın'- Uluslarararası sempozyum bildiri kitabl-Edebiyat, dil ve kültür çalışmalarında kadın, (444-449), Eskişehir: Anadolu Üniversitesi.

Szerb, A. (2008). Dünya yazın tarihi. (V. Yıldırım. Çev.) Ankara: Dost.

Tanpınar, A.H. (1971). Yahya Kemal. Edebiyata dair. İstanbul: Baha.

Taşkın, Y. (2013). Muhafazakârlı̆̆ın uslanmaz çocuğu reaksiyonerlik. A. Çiğdem (Ed.). Modern Türkiye'de siyasi düşünce. Cilt 5. Muhafazakârlık (ss.187-215). İstanbul: İletişim.

Taşkın, Y. (2013). Muhafazakâr bir proje olarak Türk-İslam sentezi. A. Çiğdem (Ed.). Modern Türkiye'de siyasi düşünce. Cillt 5/ Muhafazakârlı (ss. 381-401). İstanbul: İletişim.

Tekelioğlu, O. (2003). Edebiyatta tekil bir ulusal kanonun oluşmasının imkânsızlığı üzerine. Doğu Batı, 6 (22), 65- 77.

Tezgör, H. (2013). “Bin atlı akınlarda çocuklar”-Ortaokul Türkçe ders kitaplarında şiir (19292005). İstanbul: İletişim.

Timur, K. (2014). Mithat Cemal Kuntay’ın gözüyle Mehmet Akif. Dicle Üniversitesi Sosyal Bilimler Enstitüsü Dergisi, 6 (11), 53-78.

Troubina, L. Chertov, V. (2012). La littérature dans l'enseignement scolaire en Russie, Çev: Louise Gabanou-Priselkow, Olga Zoubovitch and Marie-José Sanselme, Revue Internationale d'Education Sevres, Dossie Ensegnement et Literature dans le Monde, 81-90.

Uyanık, N. (2015). Mehmet Akif'te çağdaşlaşma anlayışı ve bu eksende bazı meselelere bakış. Şehirlerin sevdalısı İbrahim Hakkı Konyalı armă̆anı, Konya: Selçuk Üniversitesi Türkiyat Araştırmaları Enstitüsü. 7, 535-559.

Zürcher, E. J. (2016). Modernleşen Türkiye’nin tarihi. (Y. Soner. Çev.) İstanbul: İletişim.

\section{Elektronik kaynaklar}

Fransa Ulusal Eğitim Bakanlığı (2018, 18 Kasım). Erişim adresi:

http://www.education.gouv.fr/pid285/bulletin_officiel.html?cid_bo=94717.

İngiltere Hükümeti (2018, 18 Kasım). Erişim adresi: https://www.gov.uk/government/publications/gcse-9-to-1-subject-level-conditions-and-requirements-for-english-literature. 


\section{Ek}

Tablo 3. 1950, 1957, 1976, 1992, 2005, 2015, 20172017 dil ve edebiyat dersi öğretim programlarında adı geçen yazar/şairler ve sıklıkları

\begin{tabular}{|c|c|c|c|c|c|c|c|c|}
\hline Yazar/Şair Adı & 1950 & 1957 & 1976 & 1992 & 2005 & 2015 & 2017 & Toplam \\
\hline Yahya Kemal Beyatlı & 1 & 1 & 8 & 1 & 0 & 8 & 1 & 20 \\
\hline Mehmet Akif Ersoy & 1 & 1 & 3 & 1 & 8 & 1 & 2 & 17 \\
\hline Necip Fazıl Kısakürek & 0 & 0 & 4 & 1 & 9 & 0 & 2 & 16 \\
\hline Ahmet Hamdi Tanpınar & 0 & 0 & 9 & 1 & 3 & 1 & 1 & 15 \\
\hline Ahmet Haşim & 1 & 1 & 4 & 1 & 8 & 0 & 0 & 15 \\
\hline Namık Kemal & 1 & 1 & 8 & 1 & 2 & 0 & 0 & 13 \\
\hline Yunus Emre & 1 & 1 & 0 & 1 & 7 & 0 & 1 & 11 \\
\hline Peyami Safa & 0 & 1 & 6 & 1 & 1 & 0 & 1 & 10 \\
\hline Halit Ziya Uşaklıgil & 1 & 1 & 5 & 1 & 0 & 0 & 0 & 8 \\
\hline Ahmet Muhip Diranas & 0 & 0 & 0 & 1 & 5 & 1 & 1 & 8 \\
\hline $\begin{array}{l}\text { Recaizade Mahmut Ek- } \\
\text { rem }\end{array}$ & 0 & 1 & 4 & 1 & 2 & 0 & 0 & 8 \\
\hline Ömer Seyfettin & 1 & 1 & 1 & 1 & 0 & 0 & 4 & 8 \\
\hline Reşat Nuri Güntekin & 1 & 1 & 2 & 1 & 2 & 1 & 0 & 8 \\
\hline Ziya Gökalp & 0 & 1 & 4 & 0 & 2 & 0 & 0 & 7 \\
\hline Abdülhak Hamid Tarhan & 1 & 1 & 5 & 0 & 0 & 0 & 0 & 7 \\
\hline Yakup K. Karaosmanoğlu & 1 & 1 & 2 & 1 & 2 & 0 & 0 & 7 \\
\hline Mustafa Kemal Atatürk & 1 & 1 & 2 & 1 & 1 & 1 & 0 & 7 \\
\hline Faruk Nafiz Çamlıbel & 0 & 0 & 4 & 1 & 1 & 0 & 0 & 6 \\
\hline Halide Edip Adıvar & 1 & 1 & 2 & 0 & 1 & 1 & 0 & 6 \\
\hline Cahit S1tk1 Taranc1 & 0 & 0 & 1 & 1 & 2 & 1 & 1 & 6 \\
\hline Mehmet Kaplan & 0 & 0 & 4 & 1 & 0 & 0 & 0 & 5 \\
\hline Ahmet Mithat & 1 & 1 & 2 & 1 & 0 & 0 & 0 & 5 \\
\hline Ziya Paşa & 1 & 1 & 2 & 1 & 0 & 0 & 0 & 5 \\
\hline Fuat Köprülü & 1 & 1 & 3 & 0 & 0 & 0 & 0 & 5 \\
\hline Cenap Şehabettin & 0 & 1 & 2 & 0 & 0 & 0 & 0 & 3 \\
\hline Cengiz Aytmatov & 0 & 0 & 0 & 1 & 0 & 0 & 2 & 3 \\
\hline Haldun Taner & 0 & 0 & 0 & 1 & 2 & 0 & 0 & 3 \\
\hline Nazım Hikmet & 0 & 0 & 0 & 0 & 2 & 0 & 1 & 3 \\
\hline Orhan Kemal & 0 & 0 & 0 & 1 & 0 & 0 & 2 & 3 \\
\hline Sezai Karakoç & 0 & 0 & 0 & 0 & 2 & 0 & 1 & 3 \\
\hline Abdülbaki Gölpınarlı & 0 & 0 & 2 & 0 & 0 & 0 & 0 & 2 \\
\hline Aşık Paşa & 0 & 0 & 0 & 0 & 2 & 0 & 0 & 2 \\
\hline
\end{tabular}




\begin{tabular}{|c|c|c|c|c|c|c|c|c|}
\hline Cemal Süreya & 0 & 0 & 0 & 0 & 2 & 0 & 0 & 2 \\
\hline Edip Cansever & 0 & 0 & 0 & 0 & 2 & 0 & 0 & 2 \\
\hline Hacı Bektaş-1 Veli & 0 & 0 & 0 & 0 & 2 & 0 & 0 & 2 \\
\hline Hoca Dehhani & 0 & 0 & 0 & 0 & 2 & 0 & 0 & 2 \\
\hline İlhan Berk & 0 & 0 & 0 & 0 & 2 & 0 & 0 & 2 \\
\hline Orhan Veli Kanık & 0 & 0 & 3 & 1 & 0 & 0 & 0 & 4 \\
\hline Ahmet Vefik Paşa & 1 & 1 & 1 & 1 & 0 & 0 & 0 & 4 \\
\hline Baki & 1 & 1 & 1 & 1 & 0 & 0 & 0 & 4 \\
\hline Behçet Necatigil & 0 & 0 & 1 & 1 & 0 & 1 & 1 & 4 \\
\hline Fuzuli & 1 & 1 & 1 & 1 & 0 & 0 & 0 & 4 \\
\hline Goethe & 1 & 1 & 1 & 1 & 0 & 0 & 0 & 4 \\
\hline Mehmet Emin Yurdakul & 1 & 1 & 1 & 1 & 0 & 0 & 0 & 4 \\
\hline Nedim & 1 & 1 & 1 & 1 & 0 & 0 & 0 & 4 \\
\hline Shakespeare & 1 & 1 & 1 & 1 & 0 & 0 & 0 & 4 \\
\hline Süleyman Çelebi & 1 & 1 & 0 & 1 & 0 & 0 & 1 & 4 \\
\hline Şinasi & 1 & 1 & 1 & 1 & 0 & 0 & 0 & 4 \\
\hline Tevfik Fikret & 1 & 1 & 1 & 1 & 0 & 0 & 0 & 4 \\
\hline Falih Rifkı Atay & 1 & 1 & 0 & 1 & 0 & 0 & 0 & 3 \\
\hline Karacaoğlan & 1 & 1 & 0 & 1 & 0 & 0 & 0 & 3 \\
\hline Montaigne & 1 & 1 & 0 & 1 & 0 & 0 & 0 & 3 \\
\hline Stendhal & 1 & 1 & 0 & 1 & 0 & 0 & 0 & 3 \\
\hline Şeyh Galip & 1 & 1 & 0 & 1 & 0 & 0 & 0 & 3 \\
\hline Tolstoy & 1 & 1 & 0 & 1 & 0 & 0 & 0 & 3 \\
\hline Abdülhak Şinasi Hisar & 0 & 0 & 1 & 1 & 1 & 0 & 0 & 3 \\
\hline Arif Nihat Asya & 0 & 0 & 1 & 0 & 1 & 0 & 1 & 3 \\
\hline Attila İlhan & 0 & 0 & 0 & 1 & 1 & 0 & 1 & 3 \\
\hline Hüseyin Rahmi Gürpınar & 1 & 1 & 0 & 0 & 1 & 0 & 0 & 3 \\
\hline Kaşgarlı Mahmut & 0 & 0 & 0 & 1 & 1 & 1 & 0 & 3 \\
\hline Memduh Şevket Esendal & 0 & 1 & 1 & 1 & 0 & 0 & 0 & 3 \\
\hline Moliere & 1 & 0 & 1 & 1 & 0 & 0 & 0 & 3 \\
\hline Nef'i & 0 & 1 & 1 & 1 & 0 & 0 & 0 & 3 \\
\hline Sait Faik Abasıyanık & 0 & 0 & 1 & 1 & 1 & 0 & 0 & 3 \\
\hline Evliya Çelebi & 1 & 0 & 0 & 1 & 0 & 1 & 0 & 3 \\
\hline Balzac & 1 & 1 & 0 & 0 & 0 & 0 & 0 & 2 \\
\hline Cicero & 1 & 1 & 0 & 0 & 0 & 0 & 0 & 2 \\
\hline Dante & 1 & 1 & 0 & 0 & 0 & 0 & 0 & 2 \\
\hline Edgar Alan Poe & 1 & 1 & 0 & 0 & 0 & 0 & 0 & 2 \\
\hline Eflatun & 1 & 1 & 0 & 0 & 0 & 0 & 0 & 2 \\
\hline
\end{tabular}




\begin{tabular}{|c|c|c|c|c|c|c|c|c|}
\hline Flaubert & 1 & 1 & 0 & 0 & 0 & 0 & 0 & 2 \\
\hline Henric Ibsen & 1 & 1 & 0 & 0 & 0 & 0 & 0 & 2 \\
\hline Mark Twain & 1 & 1 & 0 & 0 & 0 & 0 & 0 & 2 \\
\hline Pascal & 1 & 1 & 0 & 0 & 0 & 0 & 0 & 2 \\
\hline Rousseau & 1 & 1 & 0 & 0 & 0 & 0 & 0 & 2 \\
\hline Seneca & 1 & 1 & 0 & 0 & 0 & 0 & 0 & 2 \\
\hline Shiller & 1 & 1 & 0 & 0 & 0 & 0 & 0 & 2 \\
\hline Victor Hugo & 1 & 1 & 0 & 0 & 0 & 0 & 0 & 2 \\
\hline Voltaire & 1 & 1 & 0 & 0 & 0 & 0 & 0 & 2 \\
\hline Ahmet Yesevi & 0 & 0 & 0 & 0 & 1 & 1 & 0 & 2 \\
\hline Yusuf Has Hacip & 0 & 0 & 0 & 0 & 1 & 1 & 0 & 2 \\
\hline Ahmet Kutsi Tecer & 0 & 0 & 0 & 1 & 1 & 0 & 0 & 2 \\
\hline Cervantes & 1 & 0 & 0 & 1 & 0 & 0 & 0 & 2 \\
\hline Charles Dickens & 1 & 0 & 0 & 1 & 0 & 0 & 0 & 2 \\
\hline Erzurumlu Emrah & 0 & 1 & 0 & 1 & 0 & 0 & 0 & 2 \\
\hline Katip Çelebi & 1 & 0 & 0 & 1 & 0 & 0 & 0 & 2 \\
\hline Mehmet Rauf & 0 & 0 & 1 & 1 & 0 & 0 & 0 & 2 \\
\hline Mustafa Kutlu & 0 & 0 & 0 & 0 & 1 & 1 & 0 & 2 \\
\hline Naima & 1 & 0 & 0 & 1 & 0 & 0 & 0 & 2 \\
\hline Necati Cumalı & 0 & 0 & 0 & 1 & 1 & 0 & 0 & 2 \\
\hline Nurullah Ataç & 0 & 0 & 1 & 1 & 0 & 0 & 0 & 2 \\
\hline Racine & 0 & 0 & 1 & 1 & 0 & 0 & 0 & 2 \\
\hline Recep Bilginer & 0 & 0 & 0 & 1 & 1 & 0 & 0 & 2 \\
\hline Refik Erduran & 0 & 0 & 0 & 1 & 1 & 0 & 0 & 2 \\
\hline Sadi-i Şirazi & 0 & 0 & 1 & 1 & 0 & 0 & 0 & 2 \\
\hline Tagore & 0 & 0 & 1 & 1 & 0 & 0 & 0 & 2 \\
\hline Tarık Buğra & 0 & 0 & 0 & 1 & 1 & 0 & 0 & 2 \\
\hline Turan Oflazoğlu & 0 & 0 & 0 & 1 & 1 & 0 & 0 & 2 \\
\hline Vasfi Mahir Kocatürk & 0 & 0 & 1 & 1 & 0 & 0 & 0 & 2 \\
\hline Cahit Zarifoğlu & 0 & 0 & 0 & 0 & 1 & 0 & 1 & 2 \\
\hline Erdem Beyazit & 0 & 0 & 0 & 0 & 1 & 0 & 1 & 2 \\
\hline Orhan Şaşik Gökyay & 0 & 0 & 0 & 0 & 1 & 0 & 1 & 2 \\
\hline Aşık Veysel & 0 & 0 & 0 & 1 & 0 & 0 & 1 & 2 \\
\hline Bahtiyar Vahapzade & 0 & 0 & 0 & 1 & 0 & 0 & 1 & 2 \\
\hline Fazıl Hüsnü Dağlarca & 0 & 0 & 0 & 0 & 0 & 1 & 1 & 2 \\
\hline Şehriyar & 0 & 0 & 0 & 1 & 0 & 0 & 1 & 2 \\
\hline Yahya Akengin & 0 & 0 & 0 & 1 & 0 & 0 & 1 & 2 \\
\hline Zeki Ömer Defne & 0 & 0 & 0 & 1 & 0 & 0 & 1 & 2 \\
\hline
\end{tabular}




\begin{tabular}{|l|l|l|l|l|l|l|l|l|}
\hline Nihat Sami Banarlı & 0 & 0 & 1 & 0 & 0 & 0 & 0 & 1 \\
\hline Agah Sırrı Levent & 0 & 0 & 1 & 0 & 0 & 0 & 0 & 1 \\
\hline Ahmet Kabaklı & 0 & 0 & 1 & 0 & 0 & 0 & 0 & 1 \\
\hline Ali Nihat Tarlan & 0 & 0 & 1 & 0 & 0 & 0 & 0 & 1 \\
\hline Cevdet Paşa & 0 & 0 & 1 & 0 & 0 & 0 & 0 & 1 \\
\hline Emin Bülend Serdaroğlu & 0 & 0 & 1 & 0 & 0 & 0 & 0 & 1 \\
\hline Euripides & 1 & 0 & 0 & 0 & 0 & 0 & 0 & 1 \\
\hline Hafiz & 0 & 0 & 1 & 0 & 0 & 0 & 0 & 1 \\
\hline Hayyam & 0 & 0 & 1 & 0 & 0 & 0 & 0 & 1 \\
\hline Homeros & 1 & 0 & 0 & 0 & 0 & 0 & 0 & 1 \\
\hline Hüseyin Cahit Yalçın & 0 & 0 & 1 & 0 & 0 & 0 & 0 & 1 \\
\hline Hüseyin Siret & 0 & 0 & 1 & 0 & 0 & 0 & 0 & 1 \\
\hline İkbal & 0 & 0 & 1 & 0 & 0 & 0 & 0 & 1 \\
\hline İsmail Habib Sevük & 0 & 0 & 1 & 0 & 0 & 0 & 0 & 1 \\
\hline Kaygusuz Abdal & 0 & 0 & 1 & 0 & 0 & 0 & 0 & 1 \\
\hline Kenan Akyüz & 0 & 0 & 1 & 0 & 0 & 0 & 0 & 1 \\
\hline La Bruyere & 1 & 0 & 0 & 0 & 0 & 0 & 0 & 1 \\
\hline La Fontain & 1 & 0 & 0 & 0 & 0 & 0 & 0 & 1 \\
\hline Mümtaz Turhan & 0 & 0 & 1 & 0 & 0 & 0 & 0 & 1 \\
\hline Nevai & 0 & 1 & 0 & 0 & 0 & 0 & 0 & 1 \\
\hline Nihal Atsız & 0 & 0 & 1 & 0 & 0 & 0 & 0 & 1 \\
\hline Oliver Twist & 1 & 0 & 0 & 0 & 0 & 0 & 0 & 1 \\
\hline Plautus & 1 & 0 & 0 & 0 & 0 & 0 & 0 & 1 \\
\hline Sami Paşazade Sezai & 0 & 0 & 1 & 0 & 0 & 0 & 0 & 1 \\
\hline Sophokles & 1 & 0 & 0 & 0 & 0 & 0 & 0 & 1 \\
\hline Tacitius & 1 & 0 & 0 & 0 & 0 & 0 & 0 & 1 \\
\hline Vergillius & 1 & 0 & 0 & 0 & 0 & 0 & 0 & 1 \\
\hline Zihni & 0 & 1 & 0 & 0 & 0 & 0 & 0 & 1 \\
\hline Refik Halit Karay & 0 & 0 & 0 & 0 & 1 & 0 & 0 & 1 \\
\hline Abdurrahim Dede & 0 & 0 & 0 & 1 & 0 & 0 & 0 & 1 \\
\hline Abdurrahim Karakoç & 0 & 0 & 0 & 0 & 0 & 0 & 1 & 1 \\
\hline Abdülhamit Süleyman \\
Çolpan & 0 & 0 & 0 & 1 & 0 & 0 & 0 & 1 \\
\hline Adalet Ağaoğlu & 0 & 0 & 0 & 0 & 1 & 0 & 0 & 1 \\
\hline $\begin{array}{l}\text { Ahmet Hikmet Müftü- } \\
\text { oğlu }\end{array}$ & 0 & 0 & 0 & 1 & 0 & 0 & 0 & 1 \\
\hline Ahmet Oktay & 0 & 0 & 0 & 0 & 1 & 0 & 0 & 1 \\
\hline Ahmet Rasim & 0 & 0 & 0 & 1 & 0 & 0 & 0 & 1 \\
\hline & & & & & \\
\hline
\end{tabular}




\begin{tabular}{|c|c|c|c|c|c|c|c|c|}
\hline Alain & 0 & 0 & 0 & 1 & 0 & 0 & 0 & 1 \\
\hline Ali İzzet Özkan & 0 & 0 & 0 & 0 & 0 & 0 & 1 & 1 \\
\hline Ali Şir Nevai & 0 & 0 & 0 & 1 & 0 & 0 & 0 & 1 \\
\hline $\begin{array}{l}\text { Antoine de } \\
\text { Saint-Exupery }\end{array}$ & 0 & 0 & 0 & 0 & 0 & 0 & 1 & 1 \\
\hline Asaf Halet Çelebi & 0 & 0 & 0 & 0 & 0 & 0 & 1 & 1 \\
\hline Aşık Daimi & 0 & 0 & 0 & 0 & 0 & 0 & 1 & 1 \\
\hline Aşık Ömer & 0 & 0 & 0 & 1 & 0 & 0 & 0 & 1 \\
\hline Ata Atacanoğlu & 0 & 0 & 0 & 1 & 0 & 0 & 0 & 1 \\
\hline Ata Terzibaşı & 0 & 0 & 0 & 1 & 0 & 0 & 0 & 1 \\
\hline Ayas Ishaki & 0 & 0 & 0 & 1 & 0 & 0 & 0 & 1 \\
\hline Aybek & 0 & 0 & 0 & 1 & 0 & 0 & 0 & 1 \\
\hline Aziz Mahmut Hüdai & 0 & 0 & 0 & 1 & 0 & 0 & 0 & 1 \\
\hline Babur Şah & 0 & 0 & 0 & 1 & 0 & 0 & 0 & 1 \\
\hline Bayburtlu Zihni & 0 & 0 & 0 & 1 & 0 & 0 & 0 & 1 \\
\hline Bekir S1tkı Erdoğan & 0 & 0 & 0 & 0 & 0 & 0 & 1 & 1 \\
\hline Bernard Shaw & 0 & 0 & 0 & 1 & 0 & 0 & 0 & 1 \\
\hline Bilge Karasu & 0 & 0 & 0 & 0 & 1 & 0 & 0 & 1 \\
\hline Cahit Külebi & 0 & 0 & 0 & 0 & 0 & 1 & 0 & 1 \\
\hline Celil Mehmet Kulizade & 0 & 0 & 0 & 1 & 0 & 0 & 0 & 1 \\
\hline Cemil Meriç & 0 & 0 & 0 & 1 & 0 & 0 & 0 & 1 \\
\hline Cengiz Dağcı & 0 & 0 & 0 & 1 & 0 & 0 & 0 & 1 \\
\hline Cevat Fehmi & 0 & 0 & 0 & 0 & 1 & 0 & 0 & 1 \\
\hline Çehov & 0 & 0 & 0 & 0 & 0 & 0 & 1 & 1 \\
\hline Dadaloğlu & 0 & 0 & 0 & 1 & 0 & 0 & 0 & 1 \\
\hline Davut Sulari & 0 & 0 & 0 & 0 & 0 & 0 & 1 & 1 \\
\hline Dostoyevski & 0 & 0 & 0 & 0 & 0 & 0 & 1 & 1 \\
\hline Edip Ahmet Yükneki & 0 & 0 & 0 & 0 & 0 & 1 & 0 & 1 \\
\hline Enderunlu Vasıf & 0 & 0 & 0 & 1 & 0 & 0 & 0 & 1 \\
\hline Ercişli Emrah & 0 & 0 & 0 & 1 & 0 & 0 & 0 & 1 \\
\hline $\begin{array}{l}\text { Erzurumlu Yaşar } \\
\text { Reyhani }\end{array}$ & 0 & 0 & 0 & 1 & 0 & 0 & 0 & 1 \\
\hline Feridüddin Attar & 0 & 0 & 0 & 0 & 0 & 0 & 1 & 1 \\
\hline Ferit Edgü & 0 & 0 & 0 & 0 & 1 & 0 & 0 & 1 \\
\hline Feymani & 0 & 0 & 0 & 0 & 0 & 0 & 1 & 1 \\
\hline Füruzan & 0 & 0 & 0 & 0 & 1 & 0 & 0 & 1 \\
\hline George Orwell & 0 & 0 & 0 & 0 & 0 & 0 & 1 & 1 \\
\hline Gevheri & 0 & 0 & 0 & 1 & 0 & 0 & 0 & 1 \\
\hline
\end{tabular}




\begin{tabular}{|c|c|c|c|c|c|c|c|c|}
\hline Gülşehri & 0 & 0 & 0 & 1 & 0 & 0 & 0 & 1 \\
\hline Güngör Dilmen & 0 & 0 & 0 & 0 & 1 & 0 & 0 & 1 \\
\hline Güvahi & 0 & 0 & 0 & 1 & 0 & 0 & 0 & 1 \\
\hline Hacı Bayram Veli & 0 & 0 & 0 & 1 & 0 & 0 & 0 & 1 \\
\hline Hacı İbrahim Efendi & 0 & 0 & 0 & 0 & 1 & 0 & 0 & 1 \\
\hline Halide Nusret Zorlutuna & 0 & 0 & 0 & 1 & 0 & 0 & 0 & 1 \\
\hline Haliloğlu & 0 & 0 & 0 & 1 & 0 & 0 & 0 & 1 \\
\hline $\begin{array}{l}\text { Hamdullah Suphi } \\
\text { Tanriöver }\end{array}$ & 0 & 0 & 0 & 1 & 0 & 0 & 0 & 1 \\
\hline Henrich Böll & 0 & 0 & 0 & 1 & 0 & 0 & 0 & 1 \\
\hline Hilmi Yavuz & 0 & 0 & 0 & 0 & 1 & 0 & 0 & 1 \\
\hline İlhan Geçer & 0 & 0 & 0 & 0 & 1 & 0 & 0 & 1 \\
\hline İsmail Gaspıralı & 0 & 0 & 0 & 1 & 0 & 0 & 0 & 1 \\
\hline İsmet Özel & 0 & 0 & 0 & 0 & 0 & 0 & 1 & 1 \\
\hline Kadı Burhaneddin & 0 & 0 & 0 & 1 & 0 & 0 & 0 & 1 \\
\hline Karslı Murat Çobanoğlu & 0 & 0 & 0 & 1 & 0 & 0 & 0 & 1 \\
\hline Keçecizade İzzet Molla & 0 & 0 & 0 & 1 & 0 & 0 & 0 & 1 \\
\hline Kemal Tahir & 0 & 0 & 0 & 1 & 0 & 0 & 0 & 1 \\
\hline Kemalettin Kamu & 0 & 0 & 0 & 0 & 1 & 0 & 0 & 1 \\
\hline Kipling & 0 & 0 & 0 & 1 & 0 & 0 & 0 & 1 \\
\hline Knut Hamsun & 0 & 0 & 0 & 1 & 0 & 0 & 0 & 1 \\
\hline Mağcan Cumabayılı & 0 & 0 & 0 & 1 & 0 & 0 & 0 & 1 \\
\hline Mahsuni Şerif & 0 & 0 & 0 & 0 & 0 & 0 & 1 & 1 \\
\hline Mehmet Çınarlı & 0 & 0 & 0 & 0 & 1 & 0 & 0 & 1 \\
\hline Mehmet Hilmi & 0 & 0 & 0 & 1 & 0 & 0 & 0 & 1 \\
\hline Mevlana & 0 & 0 & 0 & 1 & 0 & 0 & 0 & 1 \\
\hline Mütercim Asım & 0 & 0 & 0 & 1 & 0 & 0 & 0 & 1 \\
\hline Nabi & 0 & 0 & 0 & 1 & 0 & 0 & 0 & 1 \\
\hline Nasreddin Hoca & 0 & 0 & 0 & 1 & 0 & 0 & 0 & 1 \\
\hline Nezihe Meriç & 0 & 0 & 0 & 0 & 1 & 0 & 0 & 1 \\
\hline Nimetullah Hafiz & 0 & 0 & 0 & 1 & 0 & 0 & 0 & 1 \\
\hline Niyazi Misri & 0 & 0 & 0 & 1 & 0 & 0 & 0 & 1 \\
\hline $\begin{array}{l}\text { Niyazi Yıldırım } \\
\text { Gençosmanoğlu }\end{array}$ & 0 & 0 & 0 & 0 & 0 & 0 & 1 & 1 \\
\hline Oğuz Atay & 0 & 0 & 0 & 0 & 1 & 0 & 0 & 1 \\
\hline Orhan Asena & 0 & 0 & 0 & 1 & 0 & 0 & 0 & 1 \\
\hline Orhan Pamuk & 0 & 0 & 0 & 0 & 1 & 0 & 0 & 1 \\
\hline Osman Türkay & 0 & 0 & 0 & 1 & 0 & 0 & 0 & 1 \\
\hline
\end{tabular}




\begin{tabular}{|l|l|l|l|l|l|l|l|l|}
\hline Özker Yaşin & 0 & 0 & 0 & 1 & 0 & 0 & 0 & 1 \\
\hline Peçevi & 0 & 0 & 0 & 1 & 0 & 0 & 0 & 1 \\
\hline Rasim Özdenören & 0 & 0 & 0 & 0 & 1 & 0 & 0 & 1 \\
\hline Recep Küpçü & 0 & 0 & 0 & 1 & 0 & 0 & 0 & 1 \\
\hline Ruşen Eşref Ünaydın & 0 & 0 & 0 & 1 & 0 & 0 & 0 & 1 \\
\hline Ruza Tevfik Bölükbaş1 & 0 & 0 & 0 & 1 & 0 & 0 & 0 & 1 \\
\hline Sabahattin Kudret Aksal & 0 & 0 & 0 & 1 & 0 & 0 & 0 & 1 \\
\hline Sadık Şendil & 0 & 0 & 0 & 0 & 0 & 0 & 1 & 1 \\
\hline Sedat Umran & 0 & 0 & 0 & 0 & 0 & 0 & 1 & 1 \\
\hline Sefil Selimi & 0 & 0 & 0 & 0 & 0 & 0 & 1 & 1 \\
\hline Semiha Ayverdi & 0 & 0 & 0 & 0 & 1 & 0 & 0 & 1 \\
\hline Seydi Ali Reis & 0 & 0 & 0 & 1 & 0 & 0 & 0 & 1 \\
\hline Seyrani & 0 & 0 & 0 & 1 & 0 & 0 & 0 & 1 \\
\hline Sinan Paşa & 0 & 0 & 0 & 1 & 0 & 0 & 0 & 1 \\
\hline Suut Kemal Yetkin & 0 & 0 & 0 & 1 & 0 & 0 & 0 & 1 \\
\hline Süreyya Berfe & 0 & 0 & 0 & 0 & 0 & 0 & 1 & 1 \\
\hline Şeref Taşlıva & 0 & 0 & 0 & 1 & 0 & 0 & 0 & 1 \\
\hline Şeyhi & 0 & 0 & 0 & 1 & 0 & 0 & 0 & 1 \\
\hline T.S. Eliot & 0 & 0 & 0 & 1 & 0 & 0 & 0 & 1 \\
\hline Taşlıalı Yahya & 0 & 0 & 0 & 1 & 0 & 0 & 0 & 1 \\
\hline Turgut Özakman & 0 & 0 & 0 & 0 & 1 & 0 & 0 & 1 \\
\hline Turgut Uyar & 0 & 0 & 0 & 0 & 0 & 0 & 1 & 1 \\
\hline Verlaine & 0 & 0 & 0 & 1 & 0 & 0 & 0 & 1 \\
\hline Vüs'at O Bener & 0 & 0 & 0 & 0 & 1 & 0 & 0 & 1 \\
\hline Yaşar Kemal & 0 & 0 & 0 & 1 & 0 & 0 & 0 & 1 \\
\hline Yavuz Bülent Bakiler & 0 & 0 & 0 & 0 & 0 & 0 & 1 & 1 \\
\hline Yenişehirli Avni & 0 & 0 & 0 & 1 & 0 & 0 & 0 & 1 \\
\hline Yusuf Atılgan & 0 & 0 & 0 & 0 & 1 & 0 & 0 & 1 \\
\hline Yusuf Ziya Ortaç & 0 & 0 & 0 & 1 & 0 & 0 & 0 & 1 \\
\hline Ziya Osman Saba & 0 & 0 & 0 & 0 & 0 & 0 & 1 & 1 \\
\hline Ziya Samedi & 0 & 0 & 0 & 1 & 0 & 0 & 0 & 1 \\
\hline & & & & & & & \\
\hline
\end{tabular}

